NISTIR 7895

\title{
NIST/NIH Vitamin D Metabolites Quality Assurance Program Report of Participant Results: Summer 2012 Comparability Study (Exercise 6)
}

Katrice A. Lippa

Mary Bedner 
NISTIR 7895

\section{NIST/NIH Vitamin D Metabolites Quality Assurance Program Report of Participant Results: Summer 2012 Comparability Study (Exercise 6)}

Katrice A. Lippa

Mary Bedner

Chemical Sciences Division

Material Measurement Laboratory

http://dx.doi.org/10.6028/NIST.IR.7895

March 2013

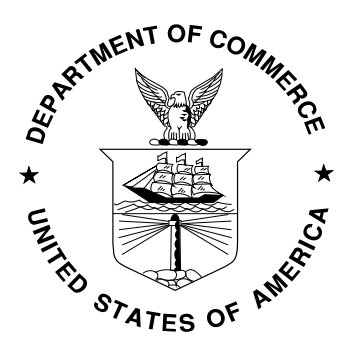

U.S. Department of Commerce Rebecca Blank, Acting Secretary

National Institute of Standards and Technology Patrick D. Gallagher, Under Secretary of Commerce for Standards and Technology and Director 


\begin{abstract}
The National Institute of Standards and Technology (NIST) recently established a Vitamin D Metabolites Quality Assurance Program (VitDQAP) in collaboration with the National Institutes of Health (NIH) Office of Dietary Supplements. Participants in the sixth exercise of this program, the Summer 2012 Comparability Study, were asked to use the methodology of their choice to measure concentrations of 25-hydroxyvitamin D in control and study materials distributed by NIST. The study materials consisted of SRM 968e Fat-Soluble Vitamins, Carotenoids, and Cholesterol in Human Serum Level 1 and SRM 972a Vitamin D Metabolites in Human Serum Level 1 and Level 3. SRM 2972, which is comprised of separate ethanolic calibration solutions with known concentrations of $25(\mathrm{OH}) \mathrm{D}_{2}$ and $25(\mathrm{OH}) \mathrm{D}_{3}$, was provided as a control material. Participants provided their data to NIST, where it was compiled and evaluated for trueness relative to the NIST value and concordance within the participant community. A report of results was provided to all participants of the study, and laboratories were identified by code numbers known only to them. The results from this sixth study are reported along with a summary of the analytical methods used.
\end{abstract}




\section{OVERVIEW OF THE SUMMER 2012 COMPARABILITY STUDY}

For the Summer 2012 Comparability Study (Exercise 6) of VitDQAP, control and human serum study samples were distributed to participants for evaluation. SRM 2972, which is comprised of separate ethanolic solutions with known concentrations of 25-hydroxyvitamin $\mathrm{D}_{2}\left(25(\mathrm{OH}) \mathrm{D}_{2}\right)$ and 25-hydroxyvitamin $\mathrm{D}_{3}\left(25(\mathrm{OH}) \mathrm{D}_{3}\right)$, was provided as a control material for assay calibration or verification. Participants were asked to provide results for single measurements of each of these solutions. In addition, participants were asked to determine 25-hydroxyvitamin D in four samples of human serum (study materials). Individual concentration values for $25(\mathrm{OH}) \mathrm{D}_{2}, 25(\mathrm{OH}) \mathrm{D}_{3}$, and 3-epi-25-hydroxyvitamin $\mathrm{D}_{3}$ (3-epi-25(OH) $\mathrm{D}_{3}$ ) were requested along with a total concentration of 25-hydroxyvitamin $\mathrm{D}\left(25(\mathrm{OH}) \mathrm{D}_{\text {Total }}=25(\mathrm{OH}) \mathrm{D}_{2}+25(\mathrm{OH}) \mathrm{D}_{3}\right)$ for each of four samples $\mathrm{A}, \mathrm{B}, \mathrm{C}$, and D. In this study, A, B, C, and D were all blended human serum pools with endogenous 25(OH)D levels. Vial A was SRM 972a Vitamin D Metabolites in Human Serum Level 1 (SRM 972a L1), and vial B was SRM 972a Level 3 (SRM 972a L3). Vials C and D were duplicate samples of SRM 968d Fat-Soluble Vitamins, Carotenoids and Cholesterol in Human Serum Level 1 (SRM 968d L1).

There were a total of 48 participants and 56 datasets (eight participants provided data for two different methods) in the Summer 2012 study. Eighteen of the datasets originated from immunoassay (IA) techniques, including three from enzyme immunoassay (EIA), 11 from chemiluminescence immunoassay (CLIA), and four from radioimmunoassay (RIA). Appendix A-1 summarizes the IA methods used by the participants. Thirty-eight of the datasets originated from liquid chromatographic (LC) methods; of those, 32 were from LC with tandem mass spectrometric detection (LC-MS ${ }^{\mathrm{n}}$ ), and six were from LC with ultraviolet absorbance detection (LC-UV). A summary of the LC methods used by the participants may be found in Appendices A-2 and A-3.

The raw data received from all participants are summarized in Appendices B-1 and B-2. All datasets from the immunoassay methods reported single values for $25(\mathrm{OH}) \mathrm{D}_{\text {Total }}$ in SRM 972a L1, SRM 972a L3, and SRM 968d L1. LC participants provided values for $25(\mathrm{OH}) \mathrm{D}_{2}, 25(\mathrm{OH}) \mathrm{D}_{3}$, and

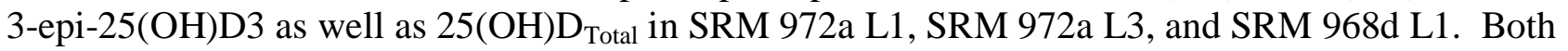
$\mathrm{LC}$ and immunoassay datasets provided individual values for $25(\mathrm{OH}) \mathrm{D}_{2}$ and $25(\mathrm{OH}) \mathrm{D}_{3}$ in the ethanolic controls because the analytes were in separate solutions.

Both SRM 972a L1 and SRM 968d L1 contain low levels of 25(OH)D 2 (reported values ranging from $0.2 \mathrm{ng} / \mathrm{mL}$ to $0.7 \mathrm{ng} / \mathrm{mL}$ ), and most of the LC labs indicated this analyte was below their quantitation limit of $<1 \mathrm{ng} / \mathrm{mL}$ to $<7 \mathrm{ng} / \mathrm{mL}$. Conversely, SRM 972a L3 has a high level of $25(\mathrm{OH}) \mathrm{D}_{2}$, and all but two of the LC participants reported values; in addition, one LC participant reported that the $25(\mathrm{OH}) \mathrm{D}_{2}$ was below their detection limit of $4 \mathrm{ng} / \mathrm{mL}$. In addition, two LC participants provided values for 3-epi-25(OH) $\mathrm{D}_{3}$ in all three materials, one participant provided a value for SRM 972a L3 only, and two labs indicated that this analyte was below their quantitation limit of $2 \mathrm{ng} / \mathrm{mL}$ and $7 \mathrm{ng} / \mathrm{mL}$ in all three materials (Appendix B-2).

Appendices B-1 and B-2 also provide the summarized results from the National Institute of Standards and Technology (NIST) for each of the serum materials. The 25(OH)D $\mathrm{D}_{2}$ in SRM 968d L1 was below the quantitation limit $(\approx 0.5 \mathrm{ng} / \mathrm{mL})$ for the NIST method; 3-epi-25(OH) $\mathrm{D}_{3}$ was detected in SRM 968d L1 but not quantitated. 


\section{SUMMER 2012 COMPARABILITY STUDY RESULTS AND DISCUSSION}

\section{5(OH)D $D_{2}$ and $25(\mathrm{OH}) D_{3}$ in the control solutions (SRM 2972)}

For the Summer 2012 study, the control solutions were only provided to participants who requested them on their enrollment forms. A summary of the participant data for $25(\mathrm{OH}) \mathrm{D}_{2}$ and $25(\mathrm{OH}) \mathrm{D}_{3}$ in the SRM 2972 control solutions is provided in Table 1. The majority of the datasets received for the Summer 2012 study were from LC methods, and many participants using IA methods did not request the calibration solutions because of compatibility issues with their assays.

The community results are summarized at the bottom of Table $\mathbf{1}$ for all reported methods, the LC methods only, and the LC-MS ${ }^{\mathrm{n}}$ methods only. The community results include the total number of quantitative values reported $(\mathrm{N})$, the median value for each analyte, the MADe (the median absolute deviation estimate, a robust estimate of the standard deviation), and the percent coefficient of variation $(\mathrm{CV} \%)$. The community results were not calculated for the data from the IA methods because of the limited number of data reported $(\mathrm{N}=2)$.

The control materials were characterized at NIST using both gravimetry and LC-MS. Table 1 presents the NIST certified values with expanded uncertainties corresponding to 95\% confidence for SRM 2972. Participants were provided these values both on the shipping package and within the data reporting sheet so that they could qualify their methods prior to analyzing the study samples. 
Table 1. Summary of participant data and community results for $25(\mathrm{OH}) \mathrm{D}_{2}(\mathrm{ng} / \mathrm{mL})$ and $25(\mathrm{OH}) \mathrm{D}_{3}(\mathrm{ng} / \mathrm{mL})$ in the SRM 2972 control solutions.

\begin{tabular}{|c|c|c|c|c|c|}
\hline \multicolumn{3}{|c|}{$25(\mathrm{OH}) \mathrm{D}_{2}(\mathrm{ng} / \mathrm{mL})$} & \multicolumn{3}{|c|}{$25(\mathrm{OH}) \mathrm{D}_{3}(\mathrm{ng} / \mathrm{mL})$} \\
\hline & & SRM 2972 & & & SRM 2972 \\
\hline Lab & Method & Value & Lab & Method & Value \\
\hline 030 & RIA & 257.0 & 030 & RIA & 408.5 \\
\hline 056 & LC-MS/MS & 246.7 & 056 & LC-MS/MS & 346.3 \\
\hline 060 & LC-MS/MS & 210.1 & 060 & LC-MS/MS & 348.1 \\
\hline 110 & LC-UV & 239.2 & 110 & LC-UV & 335.2 \\
\hline 128 & LC-MS/MS & $\mathrm{n} / \mathrm{r}$ & 128 & LC-MS/MS & 332.0 \\
\hline 139 & LC-UV & 256.0 & 139 & LC-UV & 335.0 \\
\hline $183 b$ & CLIA & 262.4 & $183 b$ & CLIA & 336.8 \\
\hline $185 a$ & LC-MS/MS & 238.6 & $185 a$ & LC-MS/MS & 334.8 \\
\hline 194 & LC-MS/MS & 240.5 & 194 & LC-MS/MS & 335.0 \\
\hline 197 & LC-MS/MS & 238.0 & 197 & LC-MS/MS & 343.0 \\
\hline $198 a$ & LC-MS/MS & 228.2 & $198 a$ & LC-MS/MS & 324.1 \\
\hline 199 & LC-MS/MS & 249.4 & 199 & LC-MS/MS & 329.9 \\
\hline 202 & LC-MS/MS & 246.0 & 202 & LC-MS/MS & 345.0 \\
\hline 211 & LC-MS/MS & 229.0 & 211 & LC-MS/MS & 280.0 \\
\hline 216 & LC-MS/MS & 229.9 & 216 & LC-MS/MS & 343.3 \\
\hline $218 b$ & LC-MS/MS & 239.1 & $218 b$ & LC-MS/MS & 336.0 \\
\hline $228 a$ & LC-MS/MS & 217.3 & $228 a$ & LC-MS/MS & 331.5 \\
\hline 231 & LC-UV & 245.3 & 231 & LC-UV & 294.5 \\
\hline 242 & LC-MS/MS & 239.4 & 242 & LC-MS/MS & 333.4 \\
\hline 243 & LC-UV & 240.6 & 243 & LC-UV & 331.7 \\
\hline 244 & LC-MS/MS & 215.0 & 244 & LC-MS/MS & 331.0 \\
\hline 248 & LC-MS/MS & 238.6 & 248 & LC-MS/MS & 334.8 \\
\hline 249 & LC-MS/MS & 238.4 & 249 & LC-MS/MS & 324.2 \\
\hline 250 & LC-MS/MS & 281.6 & 250 & LC-MS/MS & 382.0 \\
\hline 253 & LC-MS/MS & 235.5 & 253 & LC-MS/MS & 307.0 \\
\hline & $\mathrm{N}$ & 24 & & $\mathrm{~N}$ & 25 \\
\hline$=8$ & Median & 239.2 & & Median & 334.8 \\
\hline 《ঙ & MADe & 10.7 & & MADe & 7.3 \\
\hline$\stackrel{\mathscr{E}}{E}$ & CV\% & 4.5 & & CV\% & 2.2 \\
\hline & & 22 & & $\mathrm{~N}$ & 23 \\
\hline 0 & Median & 238.9 & & Median & 334.8 \\
\hline ב & MADe & 10.1 & & MADe & 7.3 \\
\hline है & CV\% & 4.2 & & CV\% & 2.2 \\
\hline & & 18 & & $N$ & 19 \\
\hline$\sum_{\Sigma}^{\infty}$ & Median & 238.5 & & Median & 334.8 \\
\hline ú & MADe & 11.6 & & MADe & 12.2 \\
\hline & CV\% & 4.9 & & CV\% & 3.6 \\
\hline & NIST Value & 238.6 & & NIST Value & 334.0 \\
\hline & $U_{95}$ & 3.9 & & $U_{95}$ & 5.2 \\
\hline
\end{tabular}


For all participant datasets, the single data values reported for $25(\mathrm{OH}) \mathrm{D}_{2}$ and $25(\mathrm{OH}) \mathrm{D}_{3}$ in the control solutions, SRM 2972, are plotted in Figure 1. The results from immunoassay methods are displayed with closed red circles (๑), and the results from the LC-based methods are displayed with closed black squares ( $\mathbf{\square})$.

From the single reported values for all LC datasets, the consensus median and the consensus variability ( $2 \times$ MADe) were determined (reported in Table 1). In Figure 1, the solid lines ( $\longrightarrow$ ) represent the consensus median and the dashed lines (- - - -) represent the approximate 95\% confidence interval $(2 \times$ MADe) for the LC datasets; the laboratories with results that fall between the two dashed lines are within the consensus variability.

The grey-shaded bar in Figure 1 represents the interval in which NIST believes the "true value" exists for these solutions (i.e., NIST certified values with $\pm U_{95}$ expanded uncertainty). The consensus median value for the LC methods lies within the NIST expanded uncertainty range for both $25(\mathrm{OH}) \mathrm{D}_{2}$ and $25(\mathrm{OH}) \mathrm{D}_{3}$. 
Figure 1. 25(OH)D $\mathrm{D}_{2}$ and $25(\mathrm{OH}) \mathrm{D}_{3}$ values in SRM 2972 for immunoassay and LC methods. The grey-shaded bars represent the ranges bound by the NIST certified values with $\pm U_{95}$ expanded uncertainty.
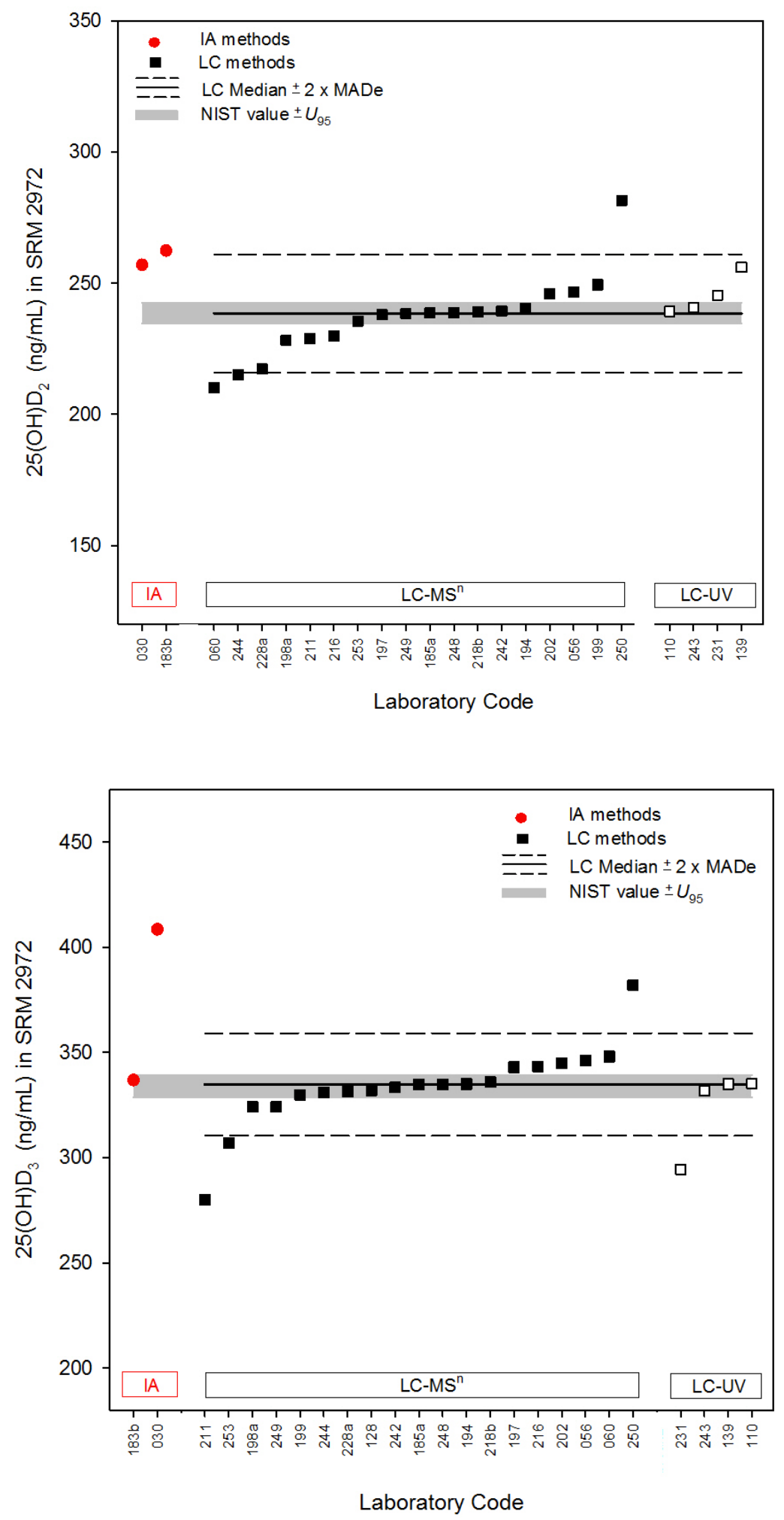


\section{5(OH)D in SRM 972a L1, SRM 972a L3, and SRM 968d L1}

A summary of the individual participant data for $25(\mathrm{OH}) \mathrm{D}_{\text {Total }}$ in SRM 972a L1 (vial A), SRM 972a L3 (vial B), and SRM 968d L1 (vials C and D) is provided in Table 2. The summarized data also include the average (mean), standard deviation (SD), and percent relative standard deviation (\%rSD) of the two reported values for SRM 968d L1.

The community results are summarized at the bottom of the table for all reported methods, the immunoassay methods only, the LC methods only, and the LC-MS ${ }^{\mathrm{n}}$ methods only. These summarized results include $\mathrm{N}$, the median value, the MADe, and the $\mathrm{CV} \%$.

Table 2 also presents the NIST results for the three study materials. For SRM 972a L1 and SRM 972a L3, the NIST result is the sum of the certified values for $25(\mathrm{OH}) \mathrm{D}_{3}$ and $25(\mathrm{OH}) \mathrm{D}_{2}$ with the corresponding $95 \%$ confidence limits $\left(U_{95}\right)$. For SRM 968d L1, the NIST value for $25(\mathrm{OH}) \mathrm{D}_{3}$ was obtained using an LC-MS/MS reference measurement procedure ${ }^{\text {a }}$ recognized by the JCTLM ( $\mathrm{N}=8$ ), and the $U_{95}$ confidence interval includes components for both measurement variability and measurement uncertainty associated with the density. The $25(\mathrm{OH}) \mathrm{D}_{2}$ was below the quantitation limit ( $\approx 0.5 \mathrm{ng} / \mathrm{mL})$ in SRM 968d L1 and was not included in the results for $25(\mathrm{OH}) \mathrm{D}_{\text {Total. }}$.

\footnotetext{
a Tai, S. S.-C., Bedner, M. and Phinney, K.W. Anal. Chem. 2010 82, 1942-1948.
} 
Table 2. Summary of participant data for $25(\mathrm{OH}) \mathrm{D}_{\text {Total }}(\mathrm{ng} / \mathrm{mL})$ in SRM 972a L1, SRM 972a L3, and SRM 968d L1.

\begin{tabular}{|c|c|c|c|c|c|c|c|c|}
\hline & & SRM 972a L1 & SRM 972a L3 & SRM 968d L1 & SRM 968d L1 & \multicolumn{3}{|c|}{ SRM 968d L1 Combined } \\
\hline $\mathrm{Lab}$ & Method & Vial A & Vial B & Vial C & Vial D & Mean & SD & \%RSD \\
\hline 017 & CLIA & 28.1 & 27.7 & 14.0 & 14.7 & 14.4 & 0.5 & 3.4 \\
\hline 026 & LC-MS/MS & 31.0 & 33.5 & 12.7 & 13.4 & 13.1 & 0.5 & 3.8 \\
\hline 030 & RIA & 32.4 & 26.7 & 15.8 & 14.4 & 15.1 & 1.0 & 6.6 \\
\hline 056 & LC-MS/MS & 30.9 & 34.8 & 12.6 & 12.3 & 12.5 & 0.2 & 1.7 \\
\hline 060 & LC-MS/MS & 37.1 & 42.2 & 15.3 & 14.6 & 15.0 & 0.5 & 3.3 \\
\hline $086 a$ & CLIA & 27.4 & 26.8 & 14.4 & 15.7 & 15.1 & 0.9 & 6.1 \\
\hline 086b & RIA & 32.0 & 40.0 & 17.0 & 17.0 & 17.0 & 0.0 & 0.0 \\
\hline 110 & LC-UV & 21.5 & 23.3 & 14.3 & 17.9 & 16.1 & 2.5 & 16 \\
\hline 116 & LC-MS/MS & 35.1 & 37.9 & 15.4 & 15.5 & 15.5 & 0.1 & 0.5 \\
\hline 128 & LC-MS/MS & 37.0 & 24.1 & 15.6 & 14.1 & 14.9 & 1.1 & 7.1 \\
\hline 139 & LC-UV & 32.0 & 34.7 & 13.0 & 13.6 & 13.3 & 0.4 & 3.2 \\
\hline 180 & RIA & 32.8 & 34.8 & 13.7 & 16.0 & 14.8 & 1.6 & 11 \\
\hline $183 b$ & CLIA & 28.0 & 25.0 & 13.8 & 13.9 & 13.9 & 0.1 & 0.5 \\
\hline $185 a$ & LC-MS/MS & 32.1 & 38.0 & 14.4 & 12.3 & 13.4 & 1.5 & 11.1 \\
\hline 187 & LC-MS/MS & 32.7 & 33.1 & 13.1 & 12.9 & 13.0 & 0.1 & 1.1 \\
\hline 188 & CLIA & 31.4 & 29.4 & 12.9 & 14.1 & 13.5 & 0.9 & 6.5 \\
\hline 189 & LC-UV & 37.7 & 14.0 & 12.0 & 10.4 & 11.2 & 1.1 & 10 \\
\hline 194 & LC-MS/MS & 32.3 & 34.1 & 12.9 & 13.1 & 13.0 & 0.1 & 1.1 \\
\hline 196 & CLIA & 31.6 & 29.2 & 14.5 & 15.6 & 15.1 & 0.8 & 5.2 \\
\hline 197 & LC-MS/MS & 32.0 & 36.3 & 13.8 & 14.3 & 14.1 & 0.4 & 2.5 \\
\hline $198 a$ & LC-MS/MS & 29.8 & 31.2 & 12.9 & 15.2 & 14.1 & 1.6 & 12 \\
\hline $198 b$ & EIA & 28.2 & 27.6 & 12.2 & 14.1 & 13.2 & 1.3 & 10 \\
\hline 199 & LC-MS/MS & 30.7 & 33.7 & 12.7 & 12.6 & 12.7 & 0.1 & 0.6 \\
\hline 202 & LC-MS/MS & 33.4 & 35.3 & 12.9 & 12.7 & 12.8 & 0.1 & 1.1 \\
\hline 209 & LC-MS/MS & 31.7 & 39.6 & 11.9 & 12.8 & 12.4 & 0.6 & 5.2 \\
\hline $210 a$ & RIA & 31.4 & 31.3 & 12.6 & 12.8 & 12.7 & 0.1 & 1.2 \\
\hline $210 b$ & CLIA & 26.8 & 26.4 & 13.2 & 13.7 & 13.5 & 0.4 & 2.6 \\
\hline 211 & LC-MS/MS & 31.5 & 34.1 & 12.3 & 11.7 & 12.0 & 0.4 & 3.5 \\
\hline 212 & LC-MS/MS & 35.4 & 44.2 & 14.7 & 15.1 & 14.9 & 0.3 & 1.9 \\
\hline $213 a$ & CLIA & 27.5 & 25.0 & 3.7 & 3.7 & 3.7 & 0.0 & 0.8 \\
\hline $213 b$ & $\mathrm{EIA}$ & 28.2 & 23.8 & 12.9 & 12.2 & 12.5 & 0.5 & 4.3 \\
\hline 215 & LC-MS/MS & 32.4 & 32.4 & 12.0 & 13.6 & 12.8 & 1.1 & 8.8 \\
\hline 216 & LC-MS/MS & 30.5 & 33.4 & 13.2 & 12.8 & 13.0 & 0.2 & 1.9 \\
\hline 217 & LC-MS/MS & 30.5 & 34.1 & 12.4 & 12.6 & 12.5 & 0.1 & 1.1 \\
\hline $218 a$ & CLIA & 29.8 & 29.2 & 13.7 & 14.7 & 14.2 & 0.7 & 5.0 \\
\hline $218 b$ & LC-MS/MS & 30.4 & 41.0 & 14.2 & 14.5 & 14.4 & 0.2 & 1.5 \\
\hline 219 & LC-MS/MS & 30.0 & 33.6 & 12.4 & 12.7 & 12.6 & 0.2 & 1.7 \\
\hline 220 & LC-MS/MS & 35.0 & 37.0 & 14.0 & 14.0 & 14.0 & 0.0 & 0.0 \\
\hline $221 a$ & LC-MS/MS & 27.9 & 31.0 & 11.6 & 12.9 & 12.3 & 0.9 & 7.5 \\
\hline $221 b$ & LC-UV & 24.4 & 28.0 & 25.0 & 24.7 & 24.9 & 0.2 & 0.9 \\
\hline 222 & CLIA & 33.1 & 35.3 & 13.5 & 12.3 & 12.9 & 0.8 & 6.6 \\
\hline $228 a$ & LC-MS/MS & 45.2 & 51.4 & 17.3 & 17.9 & 17.6 & 0.4 & 2.4 \\
\hline $228 b$ & CLIA & 30.5 & 26.7 & 3.2 & 3.1 & 3.2 & 0.0 & 1.1 \\
\hline 231 & LC-UV & 26.6 & 36.9 & 14.8 & 14.0 & 14.4 & 0.6 & 3.9 \\
\hline 234 & LC-MS/MS & 34.5 & 39.2 & 13.4 & 14.7 & 14.1 & 0.9 & 6.5 \\
\hline 241 & LC-MS/MS & 30.5 & 33.7 & 13.2 & 12.6 & 12.9 & 0.4 & 3.3 \\
\hline 242 & LC-MS/MS & 28.9 & 37.8 & 13.4 & 12.4 & 12.9 & 0.7 & 5.3 \\
\hline 243 & LC-UV & 30.1 & 38.8 & 13.6 & 12.3 & 13.0 & 0.9 & 7.0 \\
\hline 244 & LC-MS/MS & 29.0 & 34.0 & 12.0 & 11.0 & 11.5 & 0.7 & 6.1 \\
\hline $247 a$ & CLIA & 38.1 & 37.1 & 17.7 & 14.2 & 16.0 & 2.5 & 16 \\
\hline $247 b$ & $\mathrm{EIA}$ & 31.3 & 30.5 & 16.3 & 16.0 & 16.1 & 0.2 & 1.4 \\
\hline 248 & LC-MS/MS & 31.7 & 41.1 & 14.0 & 14.2 & 14.1 & 0.1 & 1.0 \\
\hline 249 & LC-MS/MS & 30.0 & 35.0 & 13.7 & 11.4 & 12.6 & 1.6 & 13 \\
\hline 250 & LC-MS/MS & 37.0 & 39.2 & 13.1 & 15.2 & 14.2 & 1.5 & 10 \\
\hline 251 & LC-MS/MS & 31.5 & 33.6 & 15.2 & 14.7 & 15.0 & 0.4 & 2.4 \\
\hline 253 & LC-MS/MS & 31.0 & 35.7 & 12.9 & 13.3 & 13.1 & 0.3 & 2.2 \\
\hline$\frac{n}{0}$ & & 56 & 56 & 56 & 56 & 56 & & \\
\hline$=\stackrel{8}{\circ}$ & Median & 31.3 & 33.9 & 13.4 & 13.8 & 13.4 & & \\
\hline$\varangle \frac{c}{d}$ & MADe & 2.1 & 5.9 & 1.2 & 1.6 & 1.3 & & \\
\hline & CV\% & 6.6 & 17 & 8.9 & 12 & 9.5 & & \\
\hline$\frac{n}{0}$ & & 18 & 18 & 18 & 18 & 18 & & \\
\hline$\varangle$ & Median & 30.9 & 28.5 & 13.7 & 14.2 & 14.0 & & \\
\hline$=\frac{1}{d}$ & MADe & 3.1 & 3.1 & 1.2 & 2.1 & 1.6 & & \\
\hline $\bar{\xi}$ & CV\% & 9.9 & 11 & 8.7 & 15 & 11 & & \\
\hline 옹 & & 38 & 38 & 38 & 38 & 38 & & \\
\hline 0 & Median & 31.5 & 34.8 & 13.2 & 13.4 & 13.1 & & \\
\hline コ吾 & MADe & 2.2 & 3.4 & 1.2 & 1.4 & 1.3 & & \\
\hline E & CV\% & 6.8 & 9.8 & 9.0 & 11 & 9.9 & & \\
\hline & $\mathrm{N}$ & 32 & 32 & 32 & 32 & 32 & & \\
\hline$\sum$ & Median & 31.6 & 34.9 & 13.1 & 13.2 & 13.0 & & \\
\hline ن̀ & MADe & 1.7 & 2.9 & 1.1 & 1.3 & 1.1 & & \\
\hline & CV\% & 5.4 & 8.3 & 8.3 & 10 & 8.3 & & \\
\hline & NIST Value & 29.3 & 33.2 & 12.4 & 12.4 & 12.4 & & \\
\hline & $U_{95}$ & 1.1 & 0.6 & 0.3 & 0.3 & 0.3 & & \\
\hline
\end{tabular}


For all participant datasets, the single reported values for $25(\mathrm{OH}) \mathrm{D}_{\text {Total }}$ in SRM 972a L1 and SRM 972a L3 and the average reported values ( \pm 2 SD) for SRM 968d L1 are plotted in Figure 2. The results from immunoassay methods are displayed with closed red circles (•), and the results from the LC-based methods are displayed with closed black squares ( $\mathbf{n})$. Each figure also has a legend that indicates which individual methods were used to obtain the reported values: IA, LC$\mathrm{MS}^{\mathrm{n}}$, or LC-UV.

From the average values for all datasets for a given technique (IA or LC), the consensus median and the consensus variability ( $2 \times$ MADe) were determined (reported in Table 2$)$. For each of the techniques within both graphs, the solid lines $(-)$ represent the consensus median and the dashed lines (- - - -) represent approximate 95\% confidence intervals ( $2 \times$ MADe).

For the IA data for SRM 972a L1, the consensus variability based on MADe is an overestimation of the 95\% confidence limits about the median (Figure 2). This stems from the non-Gaussian data distribution that contributes to a relatively wide distribution of central $50 \%$ of this data, resulting in a large MADe.

For the LC datasets for SRM 972a L1 and for both the LC and IA datasets for SRM 972a L3and SRM 968d L1, the laboratories with results that fall between the two dashed lines are within the consensus variability area for their technique (IA or LC). The grey-shaded bar for each figure represents the NIST value and its associated uncertainty (i.e., value $\pm U_{95}$ ). NIST believes that the "true" value for each material lies within this interval. When this bar is not within the consensus range, then there may be method bias.

Specific results as assessed from Figure 2 are summarized below.

\section{SRM 972a L1}

- For the IA results, the data appear to be non-normally distributed, and the consensus variability is not well-described with a MADe estimation.

- For the LC results, eight datasets are outside of the consensus variability range (four LC-MS ${ }^{\mathrm{n}}$, four LC-UV).

- The consensus median value for the LC results is slightly higher than the consensus median value for the IA results; both LC and IA median values are $\approx 5 \%$ higher than the NIST expanded uncertainty range (grey-shaded bar).

- The NIST expanded uncertainty range (grey-shaded bar) falls within the consensus variability ranges both for LC and IA results.

SRM 972a L3

- For the IA results, four datasets are outside the consensus variability range.

- For the LC results, six datasets are outside of the consensus variability range (four LC-MS ${ }^{\mathrm{n}}$, two LC-UV).

- The consensus median value for the IA results is considerably lower $(\approx 25 \%)$ than the consensus median value for the LC results; the IA median value is $\approx 15 \%$ lower than the NIST expanded uncertainty range (grey-shaded bar) whereas the LC median value is $\approx 5 \%$ higher than the NIST expanded uncertainty range. 
- The NIST expanded uncertainty range (grey-shaded bar) falls within the consensus variability ranges for both IA and LC results.

\section{SRM 968d L1}

- For the IA results, two mean values are outside of the consensus variability range.

- For the LC results, three mean values are outside of the consensus variability range (one LC$\mathrm{MS}^{\mathrm{n}}$, two LC-UV).

- The consensus median value for the IA results is marginally higher $(\approx 5 \%)$ than the consensus median value for the LC results; both LC and IA median values are higher than the NIST expanded uncertainty range (grey-shaded bar).

- The NIST expanded uncertainty range (grey-shaded bar) falls within the consensus variability range for both LC and IA.

For SRM 972a L1 and SRM 968d L1, the majority of the participant values for $25(\mathrm{OH}) \mathrm{D}_{\text {Total }}$ are higher than the NIST value, regardless of technique used (IA or LC) (Figure 2). In addition, the consensus variability is similar for those two materials ( $\approx 7 \%$ to $10 \%$ ) when the results from all methods are considered (Table 2). However, for SRM 972a L3, the majority of the LC results are higher than the NIST value, whereas the majority of the IA results are lower than the NIST value (Figure 2); the consensus variability is 17\% for SRM 972a L3 when the results for all methods are considered (Table 2). The difference in results for SRM 972a L1 and SRM 968d L1 versus SRM 972a L3 is most likely attributable to the large contribution of $25(\mathrm{OH}) \mathrm{D}_{2}$ to $25(\mathrm{OH}) \mathrm{D}_{\text {Total }}$ in the latter material, with the IA methods underrepresenting $25(\mathrm{OH}) \mathrm{D}_{2}$.

For SRM 972a L1, the 3-epi-25(OH)D $\mathrm{D}_{3}$ is also a significant vitamin D metabolite with a concentration of $1.84 \mathrm{ng} / \mathrm{mL} \pm 0.08 \mathrm{ng} / \mathrm{mL}$, corresponding to $\approx 6 \%$ of the $25(\mathrm{OH}) \mathrm{D}_{3}$ concentration of $28.8 \mathrm{ng} / \mathrm{mL} \pm 1.1 \mathrm{ng} / \mathrm{mL}$ (NIST values). Three of the LC-MS participants also reported values for 3-epi-25(OH)D 3 (1.5 ng/mL, $1.9 \mathrm{ng} / \mathrm{mL}$ and $2.1 \mathrm{ng} / \mathrm{mL})$ in SRM 972a L1 (Appendix B-2). Likewise, the 3-epi-25(OH) $\mathrm{D}_{3}$ also has a significant concentration of $1.18 \mathrm{ng} / \mathrm{mL} \pm 0.13 \mathrm{ng} / \mathrm{mL}$ in SRM 972a L3, or $\approx 6 \%$ of the $25(\mathrm{OH}) \mathrm{D}_{3}$ concentration of $19.8 \pm 0.5 \mathrm{ng} / \mathrm{mL}$ (NIST values), and two LC labs also provided values for this metabolite $(0.7 \mathrm{ng} / \mathrm{mL}$ and $1.4 \mathrm{ng} / \mathrm{mL})$. For the methods reported by many LC participants (Appendix A-2, A-3), the 3-epi-25(OH) $\mathrm{D}_{3}$ coelutes with $25(\mathrm{OH}) \mathrm{D}_{3}$ and is detected by the same multiple reaction monitoring (MRM) ions in MS/MS and absorbance wavelength in UV, leading to a positive bias in the $25(\mathrm{OH}) \mathrm{D}_{\text {Total }}$ results. It is unclear how the presence of 3-epi-25(OH) $\mathrm{D}_{3}$ affects the $25(\mathrm{OH}) \mathrm{D}_{\text {Total }}$ for immunoassay results. Given that the consensus median values for the LC and IA methods are generally $\approx 7 \%$ to $\approx 10 \%$ higher than the NIST value, it is likely that some of this bias is attributable to contribution from 3-epi-25(OH) $\mathrm{D}_{3}$. 
Figure 2. 25(OH) $\mathrm{D}_{\text {Total }}$ levels in SRM 972a L1, SRM 972a L3, and SRM 968d L1 as determined by immunoassay (IA) and LC (LC-MS ${ }^{\mathrm{n}}$ and LC-UV) methods. The grey-shaded bars represent the ranges bound by the NIST values with \pm estimated $U_{95}$ uncertainty.
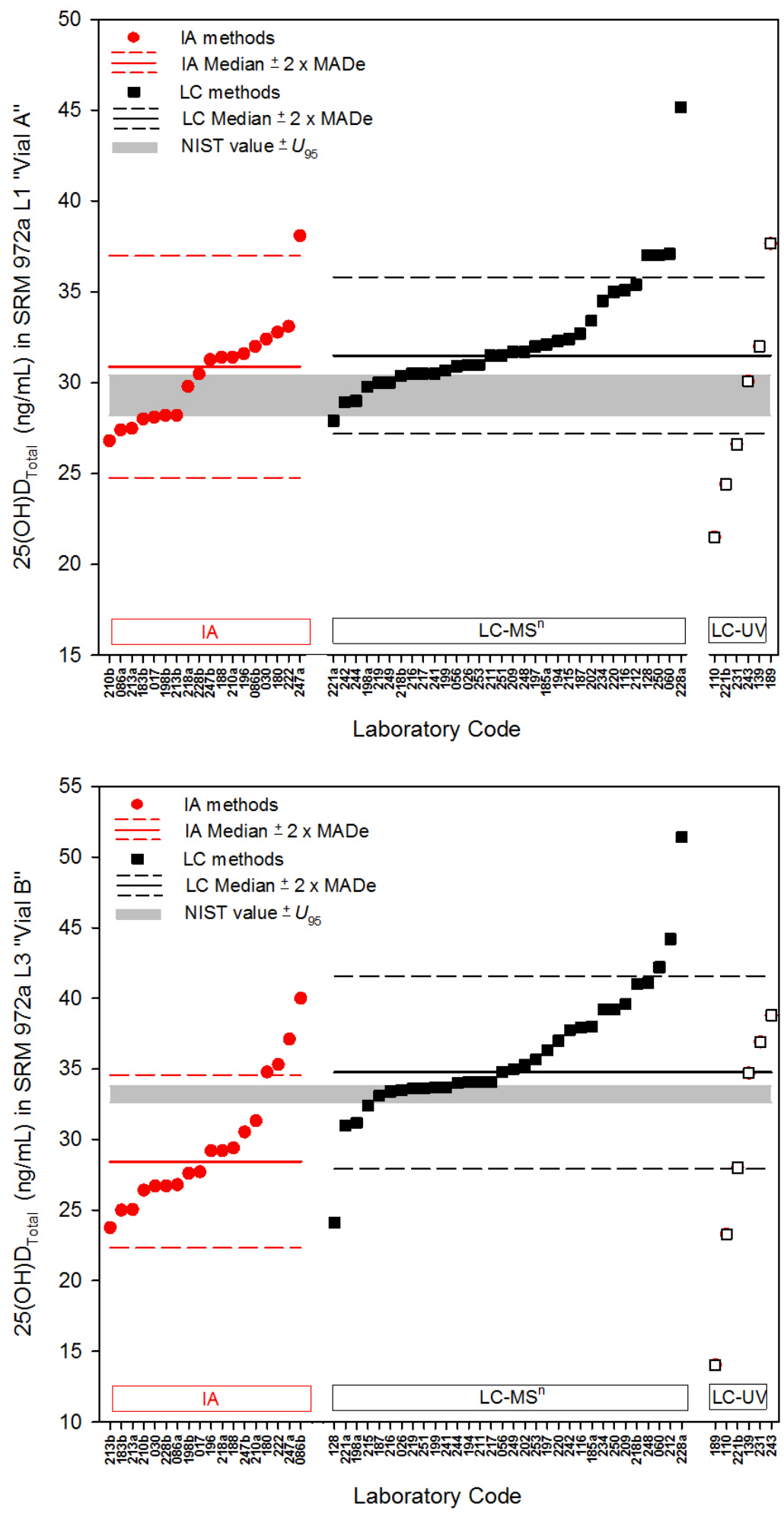
Figure 2 (cont'd). 25(OH) $\mathrm{D}_{\text {Total }}$ levels in SRM 972a L1, SRM 972a L3, and SRM 968d L1 as determined by immunoassay (IA) and LC (LC-MS ${ }^{\mathrm{n}}$ and LC-UV) methods. The grey-shaded bars represent the ranges bound by the NIST values with \pm estimated $U_{95}$ uncertainty. The error bars represent $2 \times$ SD of the duplicate results.

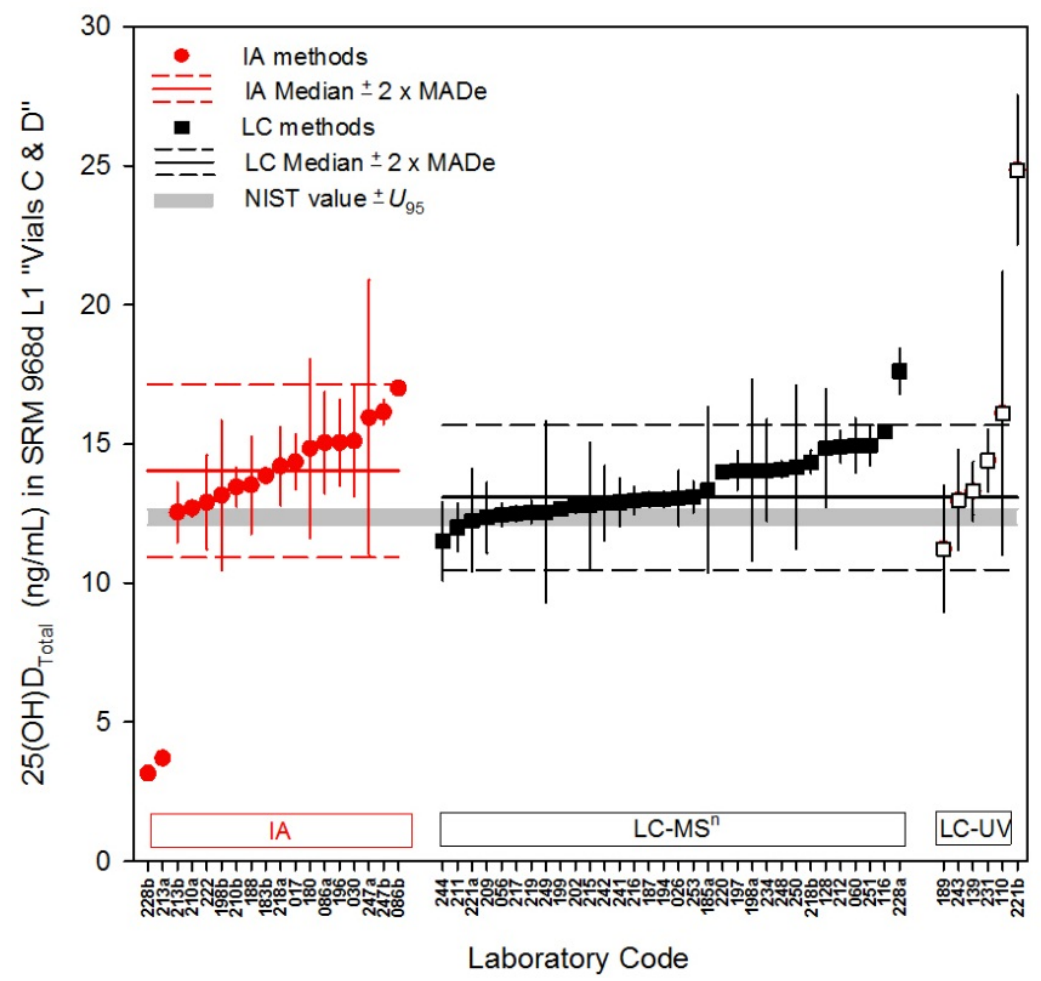


Figure 3 presents direct graphical comparisons of the $25(\mathrm{OH}) \mathrm{D}_{\text {Total }}$ results for the studied serum materials: A) SRM 972a L3 and SRM 972a L1; B) SRM 968d L1 and SRM 972a L1 and C) SRM 968d L1 and SRM 972a L3. In each plot, there are two blue consensus boxes, one for IA methods and one for LC methods (as indicated). Laboratory results that are within the consensus range for both study materials are within the blue consensus boxes. Conversely, laboratory results that fall outside of (or on the edge of) either of the consensus boxes are not included in the consensus ranges and are highlighted with their laboratory code numbers. In each plot, The NIST values for the materials are denoted with a red diamond symbol $(\diamond)$, and the Youden line $(y=x)$ centered on the NIST value is illustrated by a red line (-) across the magnitude of the $y$-axis and $\mathrm{x}$-axis, respectively.

Specific results as assessed from Figure $\mathbf{3}$ are summarized below.

SRM 972a L3 and SRM 972a L1 (Figure 3A)

- Laboratory results that are not included in the consensus ranges include numbers 060, 086b, 110, 128, 180, 189, 212, 221b, 222, 231, 247a, and 250.

- The Youden line runs through both the IA and LC consensus boxes for these materials.

- Most of the IA results for both materials are lower than the results from the LC methods, and the IA and LC consensus boxes partially overlap but exhibit significant separation from each other.

SRM 968d L1 and SRM 972a L1 (Figure 3B)

- Laboratory results that are not included in the consensus ranges include numbers $060,110,128$, 189, 213a, 221b, 228a, 228b, 231, 247a, 250.

- The Youden line runs through the center of both the IA and LC consensus boxes, illustrating that both the IA and LC results are in agreement with each other and with the NIST results for these materials.

SRM 968d L1 and SRM 972a L3 (Figure 3C)

- Laboratory results that are not included in the consensus ranges include numbers 060, 086b, 110, 128, 180, 189, 212, 213a, 221b, 222, 228a, 228b, 247a.

- The Youden line runs through the center of the LC consensus box and through the bottom corner of the IA consensus box for these materials, illustrating that the LC results are in better agreement with the NIST results for these materials.

- In general, the IA results tend to be lower than the LC results for material SRM 972a L3, leading to consensus boxes that partially overlap but exhibit significant separation from each other.

The Youden plots involving SRM 972a L3 reveal separation of the IA and LC consensus boxes, further illustrating the difference in results for the two techniques for the material with high native levels of $25(\mathrm{OH}) \mathrm{D}_{2}$. 
Figure 3. Youden comparison plot of the results for $25(\mathrm{OH}) \mathrm{D}_{\text {Total }}$ in SRM 972a L3 (Vial B) and SRM 972a L1 (Vial A) for all methods

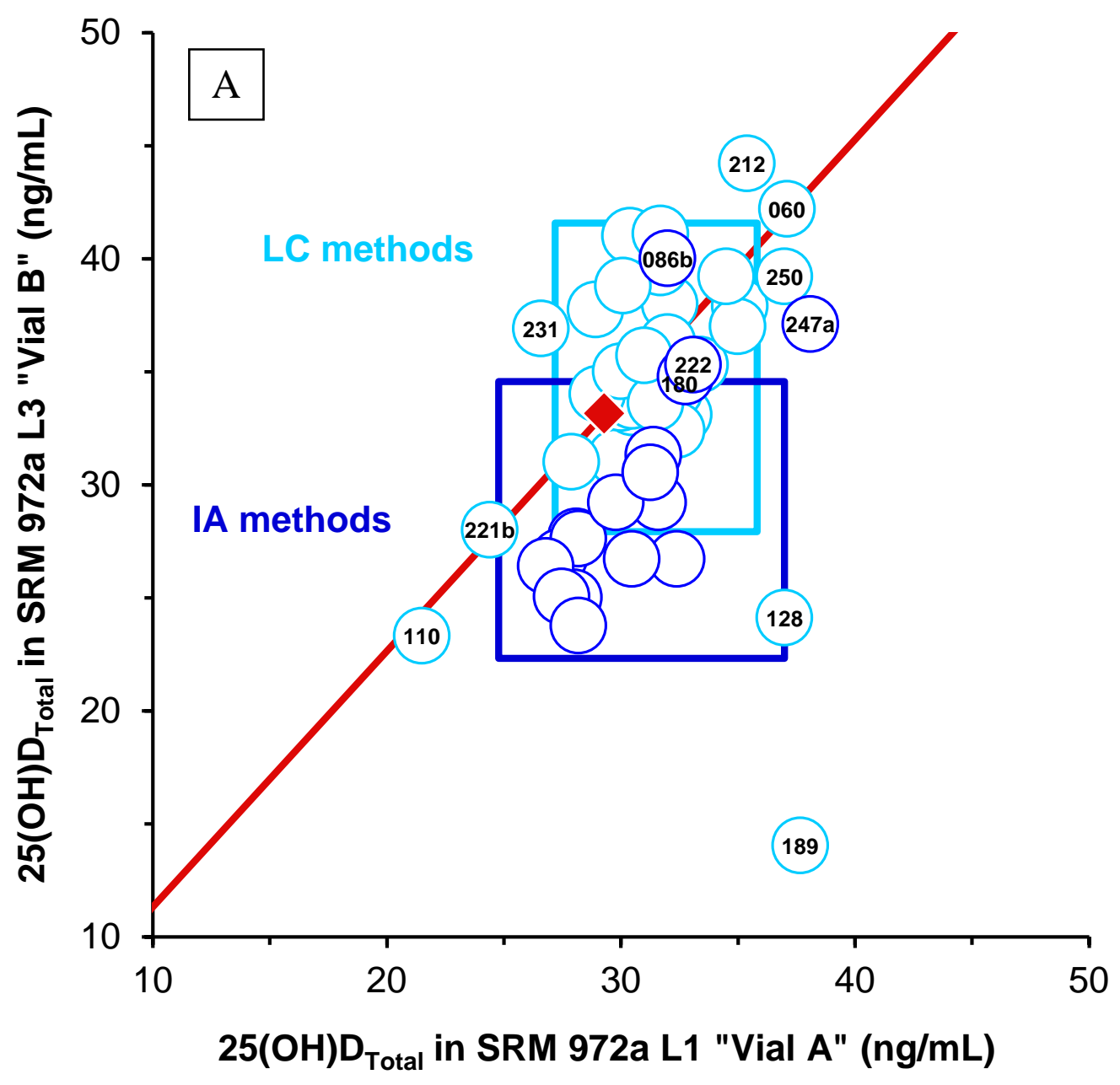

$\bigcirc \quad$ IA method laboratory values

$\square \quad$ IA method consensus box encloses \pm 2 MADe around consensus medians

$\bigcirc \quad$ LC method laboratory values

$\square \quad$ LC method consensus box encloses \pm 2 MADe around consensus medians NIST values with corresponding Youden line 
Figure 3 (cont'd). Youden comparison plot of the results for 25(OH)D Total in SRM 968d L1 (Vials C,D) and SRM 972a L1 (Vial A) for all methods

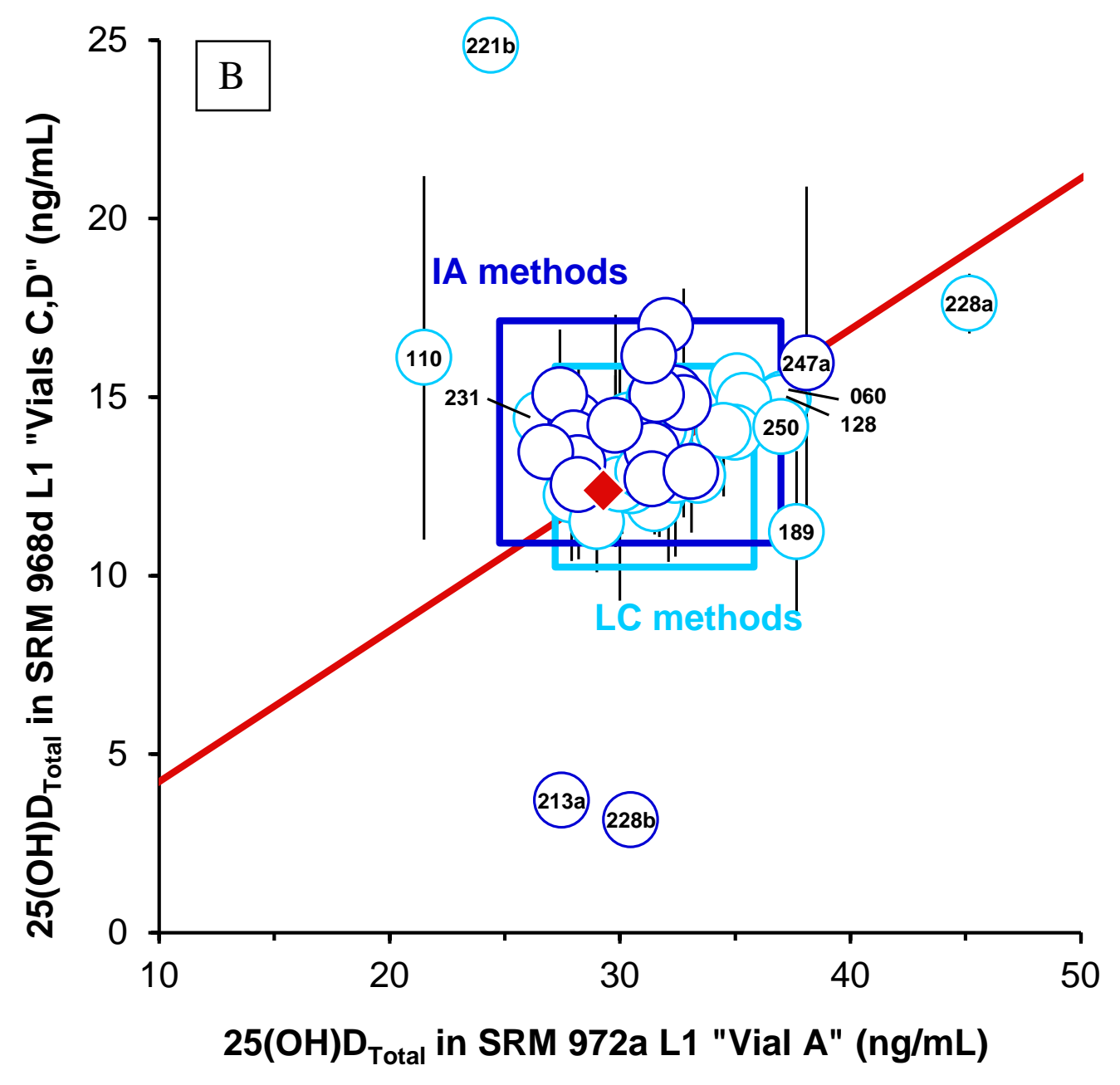

$\bigcirc \quad$ IA method laboratory mean values \pm 2 SD (y-axis only)

$\square \quad$ IA method consensus box encloses \pm 2 MADe around consensus medians

LC method laboratory mean values \pm 2 SD (y-axis only)

$\square$ LC method consensus box encloses \pm 2 MADe around consensus medians

NIST values with corresponding Youden line 
Figure 3 (cont'd). Youden comparison plot of the results for 25(OH)D $\mathrm{D}_{\text {Total }}$ in SRM 968d L1 (Vials C,D) and SRM 972a L3 (Vial B) for all methods

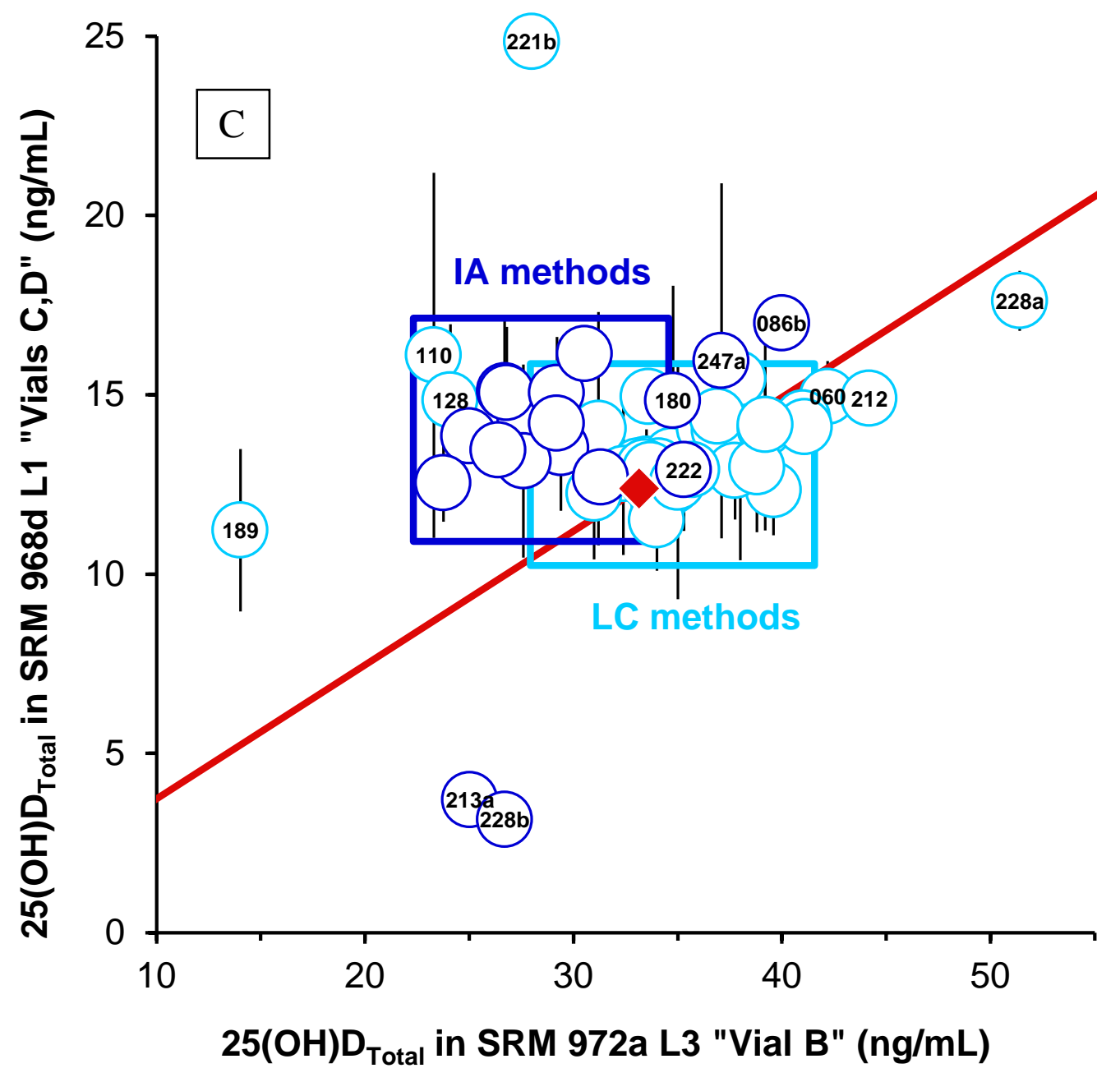

$\bigcirc \quad$ IA method laboratory mean values $\pm 2 \mathrm{SD}$ ( $\mathrm{y}$-axis only)

$\square \quad$ IA method consensus box encloses \pm 2 MADe around consensus medians

$\bigcirc \quad$ LC method laboratory mean values \pm 2 SD (y-axis only)

$\square \quad$ LC method consensus box encloses \pm 2 MADe around consensus medians NIST values with corresponding Youden line 


\section{5(OH) $D_{2}$ and 25(OH) $D_{3}$ in SRM 972a L3 (LC methods only)}

Of the two major techniques IA and LC, only the LC techniques can independently measure the $25(\mathrm{OH}) \mathrm{D}_{2}$ and $25(\mathrm{OH}) \mathrm{D}_{3}$ components of $25(\mathrm{OH}) \mathrm{D}_{\text {Total. }}$ SRM 972a L3 contains appreciable concentrations of both metabolites, and a summary of the individual LC participant data for 25(OH) $\mathrm{D}_{2}$ and 25(OH)D $\mathrm{D}_{3}$ in SRM 972a L3 (vial B) is provided in Table 3.

The community results are summarized at the bottom of the table for all LC methods and for the LC-MS ${ }^{\mathrm{n}}$ methods only. These summarized results include $\mathrm{N}$, the median value, the MADe, and the $\mathrm{CV} \%$. For the participant results, the consensus variability is much larger for $25(\mathrm{OH}) \mathrm{D}_{2}(17 \%)$ than it is for $25(\mathrm{OH}) \mathrm{D}_{3}(6 \%)$. The source of the difference in measurement uncertainty for the two metabolites is unclear.

Table 3 also presents the NIST certified values for $25(\mathrm{OH}) \mathrm{D}_{3}$ and $25(\mathrm{OH}) \mathrm{D}_{2}$ and the $95 \%$ confidence limits $\left(U_{95}\right)$ in SRM 972a L3. 
Table 3. Summary of LC participant data and community results for $25(\mathrm{OH}) \mathrm{D}_{2}(\mathrm{ng} / \mathrm{mL})$ and 25(OH) $\mathrm{D}_{3}(\mathrm{ng} / \mathrm{mL})$ in SRM 972a L3 (Vial B).

\begin{tabular}{|c|c|c|c|}
\hline & & $25(\mathrm{OH}) \mathrm{D} 2$ & $25(\mathrm{OH}) \mathrm{D} 3$ \\
\hline & & SRM 972a L3 & SRM 972a L3 \\
\hline $\mathrm{Lab}$ & Method & Vial B & Vial B \\
\hline 026 & LC-MS/MS & 13.4 & 20.1 \\
\hline 056 & LC-MS/MS & 14.7 & 20.1 \\
\hline 060 & LC-MS/MS & 17.3 & 24.9 \\
\hline 110 & LC-UV & $<4$ & 23.3 \\
\hline 116 & LC-MS/MS & 15.5 & 22.4 \\
\hline 128 & LC-MS/MS & $\mathrm{n} / \mathrm{r}$ & 24.1 \\
\hline $185 a$ & LC-MS/MS & 17.2 & 20.8 \\
\hline 187 & LC-MS/MS & 12.5 & 20.6 \\
\hline 187 & LC-MS/MS & 12.5 & 20.6 \\
\hline 189 & LC-UV & $\mathrm{n} / \mathrm{d}$ & 14.0 \\
\hline 197 & LC-MS/MS & 15.0 & 21.3 \\
\hline $198 a$ & LC-MS/MS & 12.5 & 18.7 \\
\hline $198 \mathrm{a}$ & LC-MS/MS & 12.5 & 18.7 \\
\hline 199 & LC-MS/MS & 13.2 & 20.5 \\
\hline 202 & LC-MS/MS & 13.5 & 21.8 \\
\hline 211 & LC-MS/MS & 14.1 & 20.0 \\
\hline 212 & LC-MS/MS & 22.4 & 21.8 \\
\hline 215 & LC-MS/MS & 12.0 & 20.4 \\
\hline 216 & LC-MS/MS & 13.7 & 19.7 \\
\hline 217 & LC-MS/MS & 14.1 & 20.0 \\
\hline 217 & LC-MS/MS & 14.1 & 20.0 \\
\hline $218 b$ & LC-MS/MS & 16.7 & 24.3 \\
\hline 219 & LC-MS/MS & 12.7 & 20.9 \\
\hline 220 & LC-MS/MS & 14.0 & 23.0 \\
\hline $221 a$ & LC-MS/MS & 12.4 & 18.6 \\
\hline $221 b$ & LC-UV & 11.1 & 16.9 \\
\hline $228 a$ & LC-MS/MS & 20.8 & 30.6 \\
\hline 231 & LC-UV & 15.6 & 21.3 \\
\hline 234 & LC-MS/MS & 18.9 & 20.3 \\
\hline 241 & LC-MS/MS & 13.3 & 20.4 \\
\hline 242 & LC-MS/MS & 17.9 & 19.9 \\
\hline 243 & LC-UV & 18.6 & 20.2 \\
\hline 248 & LC-MS/MS & 16.7 & 24.4 \\
\hline 249 & LC-MS/MS & 15.9 & 19.1 \\
\hline 250 & LC-MS/MS & 16.4 & 22.8 \\
\hline 251 & LC-MS/MS & 13.6 & 20.0 \\
\hline 253 & LC-MS/MS & 14.8 & 20.9 \\
\hline$\stackrel{n}{0}$ & & 34 & 37 \\
\hline 0 : & Median & 14.1 & 20.5 \\
\hline ป & MADe & 2.4 & 1.2 \\
\hline & CV\% & 17 & 5.8 \\
\hline & & 31 & 32 \\
\hline$\sum_{\Sigma}^{0}$ & Median & 14.1 & 20.6 \\
\hline $\bar{u}$ & MADe & 2.4 & 1.1 \\
\hline & CV\% & 17 & 5.2 \\
\hline & NIST Value & 13.3 & 19.8 \\
\hline & $U_{95}$ & 0.3 & 0.5 \\
\hline
\end{tabular}


For the LC participant datasets, the single data values reported for $25(\mathrm{OH}) \mathrm{D}_{2}$ and $25(\mathrm{OH}) \mathrm{D}_{3}$ in SRM 972a L3 are plotted in Figure 4 and are displayed with white triangles $(\nabla)$ and grey triangles $(\triangle)$, respectively. The values for $25(\mathrm{OH}) \mathrm{D}_{\text {Total }}$ represent the sum of $25(\mathrm{OH}) \mathrm{D}_{2}$ and $25(\mathrm{OH}) \mathrm{D}_{3}$ and are plotted as red triangles $(\triangle)$. In Figure 4, the red solid lines $(-)$ represent the consensus median and the red dashed lines (- - - -) represent the approximate 95\% confidence interval ( $2 \times$ $\mathrm{MAD}_{\mathrm{e}}$ ) for all LC method results.

The laboratories with results that fall between the two dashed lines are within the consensus variability range. For SRM 972a L3, there are three outlying LC results (one LC-MS ${ }^{\mathrm{n}}$, two LC-UV) that underestimated the $25(\mathrm{OH}) \mathrm{D}_{\text {Total }}$ either because they did not measure or did not detect the $25(\mathrm{OH}) \mathrm{D}_{2}$. For the LC methods, independent, accurate measurements of both $25(\mathrm{OH}) \mathrm{D}_{2}$ and $25(\mathrm{OH}) \mathrm{D}_{3}$ are required to obtain accurate values for $25(\mathrm{OH}) \mathrm{D}_{\text {Total }}$.

The grey-shaded bars in Figure 4 represent the interval in which NIST believes the "true value" exists for these solutions (i.e., NIST value \pm approximately 95\% confidence intervals $\left(U_{95}\right)$ ). The median results for both $25(\mathrm{OH}) \mathrm{D}_{2}$ and $25(\mathrm{OH}) \mathrm{D}_{3}$ are higher than the NIST expanded uncertainty range; however, the NIST value falls within the consensus range for the LC methods for both $25(\mathrm{OH}) \mathrm{D}_{2}$ and $25(\mathrm{OH}) \mathrm{D}_{3}$.

Figure 4. $25(\mathrm{OH}) \mathrm{D}_{2}, 25(\mathrm{OH}) \mathrm{D}_{3}$ and $25(\mathrm{OH}) \mathrm{D}_{\text {Total }}$ levels in SRM 972a L3 as determined by LC $\left(\mathrm{LC}-\mathrm{MS}^{\mathrm{n}}\right.$ and LC-UV) methods. The grey-shaded bars represent the ranges bound by the NIST values with \pm estimated $U_{95}$ uncertainty.

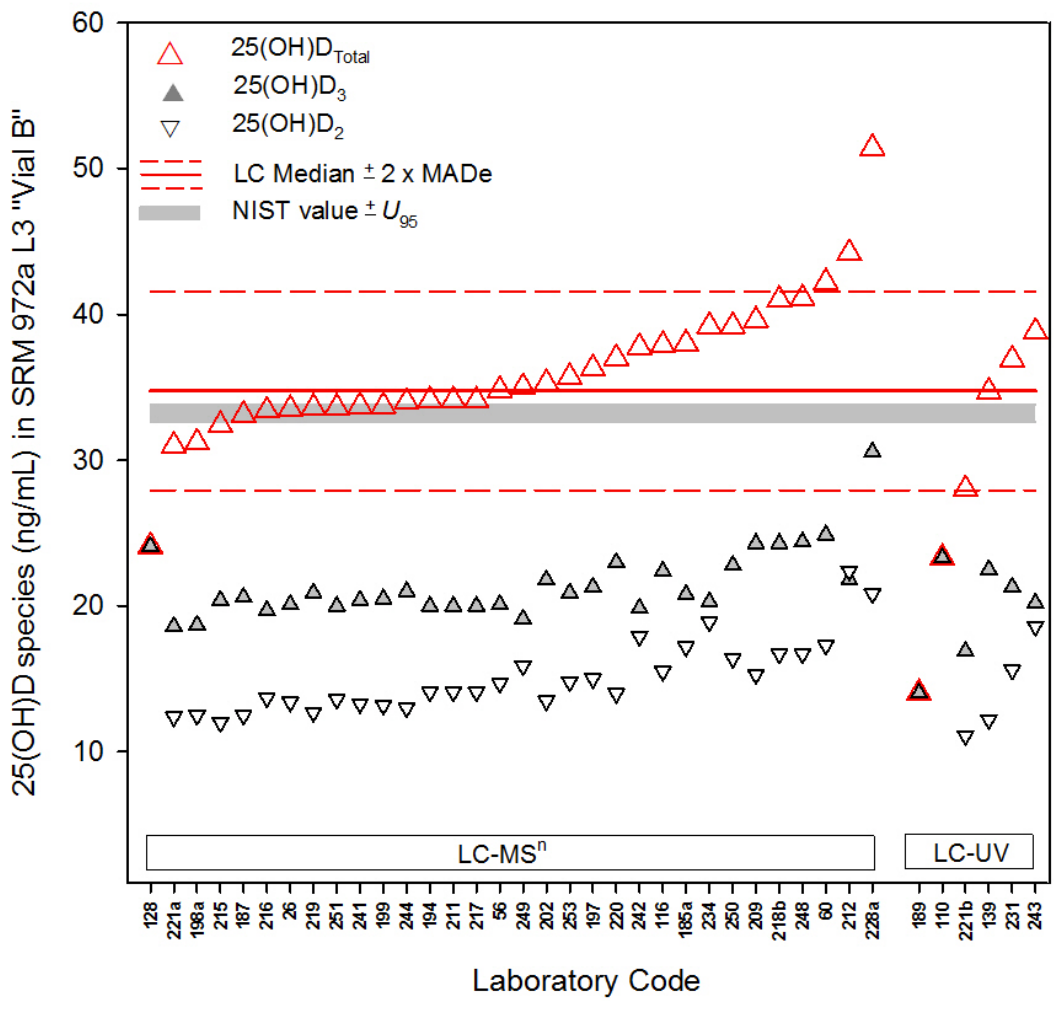




\section{Correlation of 25(OH)D in SRM 972a L1, SRM 972a L3, and SRM 968d L1 with Clinical Ranges}

The current guidance regarding $25(\mathrm{OH}) \mathrm{D}$ concentrations and human health (obtained from the NIH website) is presented in Table 4.

Table 4. Serum 25-Hydroxyvitamin D [25(OH)D] Concentrations and Health [1]

\begin{tabular}{|l|l|l|}
\hline $\mathbf{n g} / \mathbf{m L}$ & $\mathbf{n m o l} / \mathbf{L}$ & Health Status \\
\hline$<12$ & $<30$ & $\begin{array}{l}\text { Associated with vitamin D deficiency, leading to rickets } \\
\text { in infants and children and osteomalacia in adults }\end{array}$ \\
\hline $12-20$ & $30-50$ & $\begin{array}{l}\text { Generally considered inadequate for bone and overall } \\
\text { health in healthy individuals }\end{array}$ \\
\hline$\geq 20$ & $\geq 50$ & $\begin{array}{l}\text { Generally considered adequate for bone and overall } \\
\text { health in healthy individuals }\end{array}$ \\
\hline$>50$ & $>125$ & $\begin{array}{l}\text { Emerging evidence links potentially adverse effects to } \\
\text { such high levels, particularly }>150 \text { nmol/L }(>60 \mathrm{ng} / \mathrm{mL})\end{array}$ \\
\hline
\end{tabular}

Table from http://ods.od.nih.gov/factsheets/vitamind\#h4

[1] Institute of Medicine, Food and Nutrition Board. Dietary Reference Intakes for Calcium and Vitamin D. Washington, DC: National Academy Press, 2010.

Graphical representations of the participant and NIST results for SRM 972a L1, SRM 972a L3, and SRM 968d L1 overlaid with the clinical ranges for 25(OH)D from Table 4 are presented in

Figure 5. Specific results as assessed from Figure 5 are summarized below:

\section{SRM $972 a$ L1}

- All of the participant results are in the adequate $25(\mathrm{OH}) \mathrm{D}$ concentration range, but the range or reported values is large (from $21.5 \mathrm{ng} / \mathrm{mL}$ to $45.2 \mathrm{ng} / \mathrm{mL}$ ).

- $\quad$ The NIST value $(29.3 \mathrm{ng} / \mathrm{mL} \pm 1.1 \mathrm{ng} / \mathrm{mL})$ is in the adequate $25(\mathrm{OH}) \mathrm{D}$ concentration range.

SRM $972 a$ L3

- The majority of the participant results are in the adequate range, but there is one result in each of the inadequate and potentially adverse ranges; the range of participant results is large (from $14.0 \mathrm{ng} / \mathrm{mL}$ to $51.4 \mathrm{ng} / \mathrm{mL}$ ).

- $\quad$ The NIST value $(33.2 \mathrm{ng} / \mathrm{mL} \pm 0.6 \mathrm{ng} / \mathrm{mL})$ is in the adequate $25(\mathrm{OH}) \mathrm{D}$ concentration range.

\section{SRM 968d L1}

- The majority of participant results are in the inadequate $25(\mathrm{OH}) \mathrm{D}$ concentration range, but results in the deficient and adequate concentration ranges were also reported.

- $\quad$ The NIST value $(12.4 \mathrm{ng} / \mathrm{mL} \pm 0.3 \mathrm{ng} / \mathrm{mL})$ is in the inadequate $25(\mathrm{OH}) \mathrm{D}$ concentration range.

The consensus CV\% of the participant results from all methods was $\approx 10 \%$ for SRM 972a L1 and 968d L1 and 17\% for SRM 972a L3 (Table 2). Large consensus variability has implications regarding the accuracy of 25(OH)D measurements for the diagnosis of vitamin D status, particularly given the narrow ranges associated with vitamin $\mathrm{D}$ deficiency and inadequacy. 
Figure 5. 25(OH)D $\mathrm{D}_{\text {Total }}$ levels in SRM 972a L1, SRM 972a L3, and SRM 968d L1 superimposed over clinically-relevant serum 25-hydroxyvitamin D $\left(25(\mathrm{OH}) \mathrm{D}_{\text {Total }}\right)$ concentration levels as reported by NIH (Table 3). The grey-shaded bars represent the ranges bound by the NIST values with \pm estimated $U_{95}$ uncertainty.
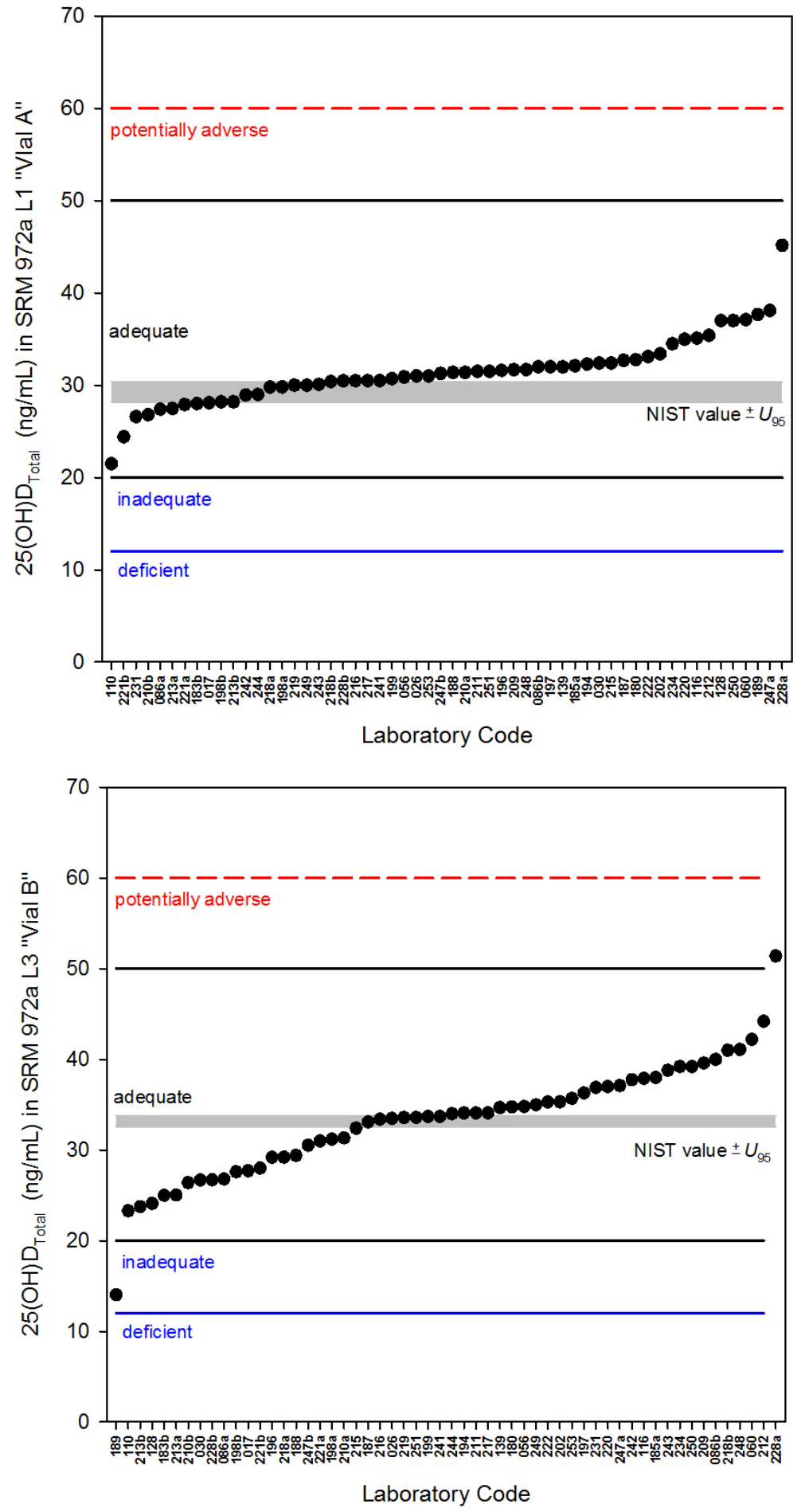
Figure 5 (cont'd) 25(OH)D $\mathrm{D}_{\text {Total }}$ levels in SRM 972a L1, SRM 972a L3, and SRM 968d L1 superimposed over clinically-relevant serum 25-hydroxyvitamin D $\left(25(\mathrm{OH}) \mathrm{D}_{\text {Total }}\right)$ concentration levels as reported by NIH (Table 3). The grey-shaded bars represent the ranges bound by the NIST values with \pm estimated $U_{95}$ uncertainty.

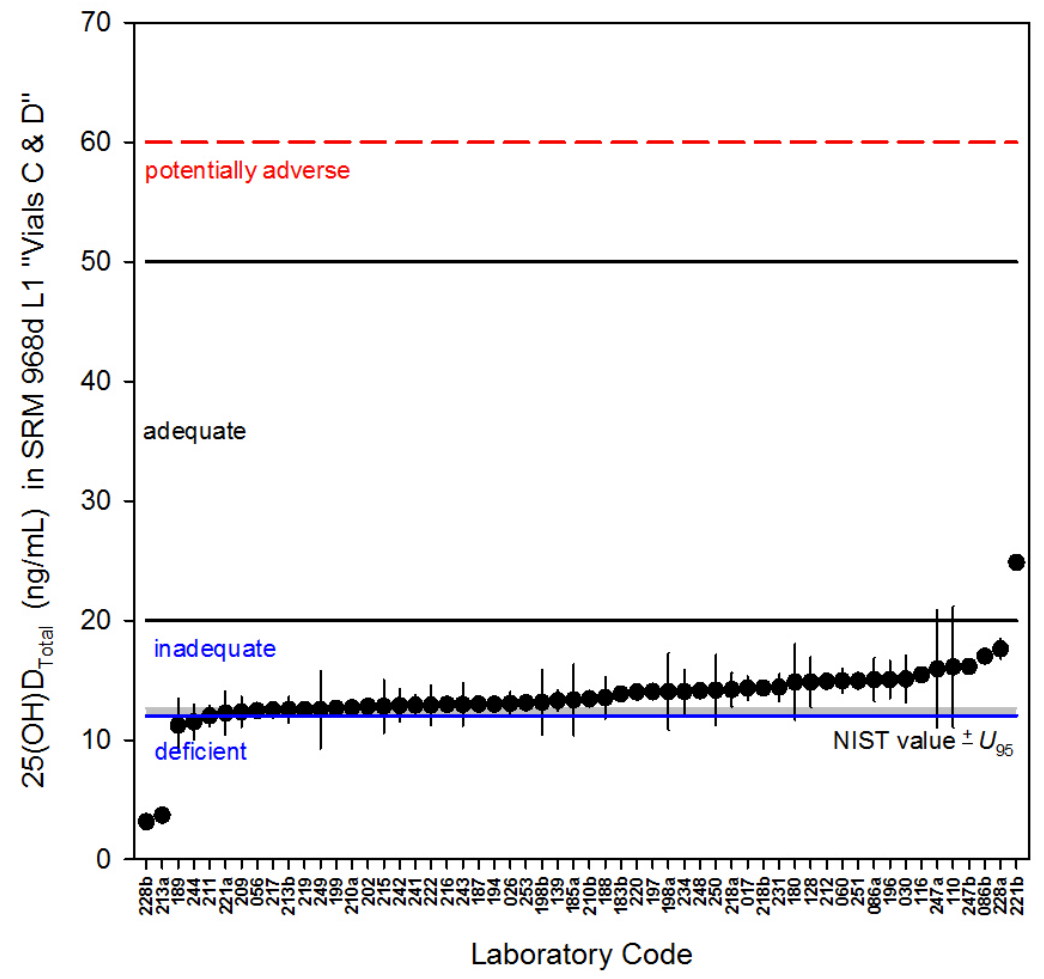


Appendix A-1. Summary of immunoassay methods used by participants.

\begin{tabular}{|c|c|c|c|}
\hline $\begin{array}{l}\text { Laboratory } \\
\text { Number }\end{array}$ & IA Method & Sample Preparation & Detection \\
\hline 17 & CLIA & $\mathrm{n} / \mathrm{r}$ & $\mathrm{n} / \mathrm{r}$ \\
\hline 30 & RIA & $\begin{array}{l}\text { Sample was extracted with acetonitrile ( } 50 \mu \mathrm{L} \text { sample }+500 \mu \mathrm{L} \\
\text { acetonitrile); controls measured using water as the diluent }\end{array}$ & $\begin{array}{l}\text { Gamma counter with data } \\
\text { reduction software }\end{array}$ \\
\hline $86 a$ & CLIA & $\mathrm{n} / \mathrm{r}$ & $\mathrm{n} / \mathrm{r}$ \\
\hline $86 b$ & RIA & $\mathrm{n} / \mathrm{r}$ & $n / r$ \\
\hline 180 & RIA & Samples extracted with acetonitrile & $1^{125}$ detection \\
\hline $183 b$ & CLIA & $\mathrm{n} / \mathrm{r}$ & $n / r$ \\
\hline 188 & CLIA & None & $n / r$ \\
\hline 196 & CLIA & $\begin{array}{l}\text { The human serum samples were analyzed neat; calibration } \\
\text { solutions were diluted 1:4 in a diluent mix and analyzed }\end{array}$ & $\mathrm{n} / \mathrm{r}$ \\
\hline $198 b$ & EIA & $\mathrm{n} / \mathrm{r}$ & $n / r$ \\
\hline $210 a$ & RIA & Sample was extracted with acetonitrile & $n / r$ \\
\hline $210 b$ & CLIA & $\mathrm{n} / \mathrm{r}$ & $\mathrm{n} / \mathrm{r}$ \\
\hline $213 a$ & EIA & Sample was thawed and gently mixed prior to analysis & $\mathrm{n} / \mathrm{r}$ \\
\hline $213 b$ & CLIA & Sample was thawed and gently mixed prior to analysis & $n / r$ \\
\hline $218 a$ & CLIA & Direct analysis & $n / r$ \\
\hline 222 & CLIA & $\mathrm{n} / \mathrm{r}$ & $n / r$ \\
\hline $228 b$ & CLIA & $\mathrm{n} / \mathrm{r}$ & $n / r$ \\
\hline $247 a$ & CLIA & Sample was thawed, mixed well and used in the assay & $\mathrm{n} / \mathrm{r}$ \\
\hline $247 b$ & EIA & Sample was thawed, mixed well and used in the assay & $\begin{array}{l}\text { UV at } 450 \mathrm{~nm} \text { with a } \\
\text { reference filter at } 630 \mathrm{~nm}\end{array}$ \\
\hline
\end{tabular}

$\mathrm{n} / \mathrm{r}=$ not reported 
Appendix A-2. Summary of LC-MS ${ }^{\mathrm{n}}$ methods reported by participants.

\begin{tabular}{|c|c|c|c|c|}
\hline $\begin{array}{l}\text { Laboratory } \\
\text { Number }\end{array}$ & $\begin{array}{c}\text { Internal } \\
\text { Standard (IS) }\end{array}$ & Sample Preparation & Chromatographic Conditions & Detection: MRM ions \\
\hline 26 & $\begin{array}{l}25(\mathrm{OH}) \mathrm{D}_{2}-d_{6} \text { and } \\
25(\mathrm{OH}) \mathrm{D}_{3}-d_{6}\end{array}$ & Liquid-liquid extraction method & $\begin{array}{l}\text { PFP column }(100 \times 3.2 \mathrm{~mm}) ; \\
\text { isocratic separation with } 82 \% \\
\text { methanol, } 18 \% \text { water; flow } 0.4 \\
\mathrm{~mL} / \mathrm{min}\end{array}$ & $\begin{array}{l}25(\mathrm{OH}) \mathrm{D}_{2} 413 / 355 \\
\text { 25(OH)D } \\
\text { 3-epi-25(OH) } \mathrm{D}_{3} 401 / 365 \\
\end{array}$ \\
\hline 56 & $\begin{array}{c}25(\mathrm{OH}) \mathrm{D}_{2}-d_{3} \\
25(\mathrm{OH}) \mathrm{D}_{3}-d_{6} \\
\text { 3-epi-25(OH) } \mathrm{D}_{3}-d_{3}\end{array}$ & $\begin{array}{l}\text { Samples were extracted with } \\
\text { hexane, evaporated, then } \\
\text { reconstituted with } 69 \% \text { methanol }\end{array}$ & $\begin{array}{l}\text { PFP column }(100 \times 2.1 \mathrm{~mm} ; 1.9 \\
\mu \mathrm{m}) ; \text { isocratic elution; flow } 0.4 \\
\mathrm{~mL} / \mathrm{min}\end{array}$ & $\begin{array}{l}25(\mathrm{OH}) \mathrm{D}_{3} 383 / 365 \\
25(\mathrm{OH}) \mathrm{D}_{3}-d_{6} 389 / 371 \\
25(\mathrm{OH}) \mathrm{D}_{2} 395 / 377 \\
25(\mathrm{OH}) \mathrm{D}_{2}-d_{3} 398 / 380 \\
3-\mathrm{epi}-25(\mathrm{OH}) \mathrm{D}_{3} 383 / 365\end{array}$ \\
\hline 60 & $25(\mathrm{OH}) \mathrm{D}_{3}-d_{6}$ & $\begin{array}{l}\text { IS was added and serum }(150 \mu \mathrm{L}) \\
\text { proteins were precipitated with } \\
\text { ternary solvent, followed by } \\
\text { centrifugation, evaporation, and } \\
\text { reconstitution }\end{array}$ & $\begin{array}{l}\text { C18 column }(150 \times 3.0 \mathrm{~mm}) \text {; } \\
\text { gradient with water, methanol and } \\
\text { acetonitrile }(0.05 \% \text { formic acid }) \text {; } \\
\text { flow } 0.55 \mathrm{~mL} / \mathrm{min}\end{array}$ & $\begin{array}{l}25(\mathrm{OH}) \mathrm{D}_{3} 383 / 211 \\
25(\mathrm{OH}) \mathrm{D}_{3}-d_{6} 389 / 211 \\
25(\mathrm{OH}) \mathrm{D}_{2} 395 / 270\end{array}$ \\
\hline 116 & $25(\mathrm{OH}) \mathrm{D}_{3}-d_{6}$ & $\begin{array}{l}\text { Serum proteins were precipitated, } \\
\text { followed by centrifugation and } \\
\text { injection of the supernatant }\end{array}$ & 2-dimensional LC-MS/MS & $\begin{array}{l}25(\mathrm{OH}) \mathrm{D}_{3} 383 / 211 \\
25(\mathrm{OH}) \mathrm{D}_{3}-d_{6} 389 / 211 \\
25(\mathrm{OH}) \mathrm{D}_{2} 395 / 269\end{array}$ \\
\hline 128 & $\mathrm{n} / \mathrm{r}$ & $\mathrm{n} / \mathrm{r}$ & $\mathrm{n} / \mathrm{r}$ & $\mathrm{n} / \mathrm{r}$ \\
\hline $185 a$ & $\begin{array}{c}25(\mathrm{OH}) \mathrm{D}_{2}-d_{6} \text { and } \\
25(\mathrm{OH}) \mathrm{D}_{3}-d_{6}\end{array}$ & $\begin{array}{l}\text { Liquid-liquid extraction; } 40 \mu \mathrm{L} \\
\text { sample }\end{array}$ & $\begin{array}{l}\text { C18 column; methanol/water } \\
\text { gradient }\end{array}$ & MRM \\
\hline 187 & $\mathrm{n} / \mathrm{r}$ & $\mathrm{n} / \mathrm{r}$ & $\mathrm{n} / \mathrm{r}$ & $\mathrm{n} / \mathrm{r}$ \\
\hline 194 & $25(\mathrm{OH}) \mathrm{D}_{3}-d_{6}$ & $\begin{array}{l}\text { Proteins precipitated with } \\
\text { acetonitrile, top layer removed, } \\
\text { evaporated, and reconstituted } \\
\text { with methanol }\end{array}$ & C8 column $(50 \times 2 \mathrm{~mm})$ & $\begin{array}{l}25(\mathrm{OH}) \mathrm{D}_{2} 395.3 / 119.0 \\
25(\mathrm{OH}) \mathrm{D}_{3} 383.4 / 211.3\end{array}$ \\
\hline 197 & $25(\mathrm{OH}) \mathrm{D}_{3}-d_{6}$ & $\begin{array}{l}\text { Precipitating agent added }(200 \mu \mathrm{L} \\
\text { with } 20 \text { ng IS) to each serum ( } 200 \\
\mu \mathrm{L}) \text {, calibrator and control sample } \\
\text { followed by mixing, centrifugation, } \\
\text { and analysis }\end{array}$ & $\begin{array}{l}\text { C18 column }(50 \times 4.6 \mathrm{~mm} ; 5 \mu \mathrm{m}) \text {; } \\
\text { column temp } 45^{\circ} \mathrm{C} \text {; gradient with } \\
\text { water and methanol; flow } 1.0 \\
\mathrm{~mL} / \mathrm{min}\end{array}$ & $n / r$ \\
\hline $198 \mathrm{a}$ & $25(\mathrm{OH}) \mathrm{D}_{3}-d_{6}$ & $\begin{array}{l}\text { Proteins precipitated with } \\
\text { methanol, followed by hexane } \\
\text { extraction, centrifugation, } \\
\text { evaporation under } \mathrm{N}_{2} \text {, and } \\
\text { reconstitution in methanol }(0.1 \% \\
\text { formic acid) }\end{array}$ & $\begin{array}{l}\text { C18 column }(50 \times 2.1 \mathrm{~mm} ; 3.5 \mu \mathrm{m}) \text {; } \\
\text { isocratic elution with } 85 \% \text { methanol } \\
(0.1 \% \text { formic acid }) \text {; flow } 0.5 \mathrm{~mL} / \mathrm{min}\end{array}$ & $\begin{array}{l}25(\mathrm{OH}) \mathrm{D}_{3} 401 / 383,401 / 365 ; \\
25(\mathrm{OH}) \mathrm{D}_{2} 413 / 395,413 / 355 ; \\
25(\mathrm{OH}) \mathrm{D}_{3}-d_{6} 407 / 389 \\
407 / 371\end{array}$ \\
\hline 199 & $\mathrm{n} / \mathrm{r}$ & $\mathrm{n} / \mathrm{r}$ & $\mathrm{n} / \mathrm{r}$ & $\mathrm{n} / \mathrm{r}$ \\
\hline 202 & $\begin{array}{l}d_{6} \text {-labeled } \\
\text { compound }\end{array}$ & Sample was extracted & $\begin{array}{l}\text { C18 column }(50 \times 2.1 \mathrm{~mm}) \text {; gradient } \\
\text { with water }(10 \mathrm{mmol} / \mathrm{L} \text { ammonium } \\
\text { formate) and methanol }(0.1 \% \text { formic } \\
\text { acid); flow } 0.4 \mathrm{~mL} / \mathrm{min}\end{array}$ & $\mathrm{n} / \mathrm{r}$ \\
\hline 209 & $25(\mathrm{OH}) \mathrm{D}_{3}-d_{6}$ & $\begin{array}{l}\text { Proteins were precipitated with } \\
\mathrm{ZnSO}_{4} \text { in methanol }\end{array}$ & $\begin{array}{l}\text { C8 column }(50 \times 2 \mathrm{~mm} ; 5 \mu \mathrm{m}) \text {; } \\
\text { gradient with water/methanol; flow } \\
0.7 \mathrm{~mL} / \mathrm{min}\end{array}$ & $\begin{array}{l}25(\mathrm{OH}) \mathrm{D}_{3} 383 / 229,383 / 211 ; \\
25(\mathrm{OH}) \mathrm{D}_{3}-d_{6} 389 / 211 ; \\
25(\mathrm{OH}) \mathrm{D}_{2} 395 / 269,395 / 119\end{array}$ \\
\hline 211 & $25(\mathrm{OH}) \mathrm{D}_{3}-d_{6}$ & $\begin{array}{l}\text { Proteins precipitated with } \\
\text { acetonitrile containing IS followed } \\
\text { by centrifugation }\end{array}$ & Column (33 x 4.6 mm; $3 \mu \mathrm{m})$ & $\begin{array}{l}25(\mathrm{OH}) \mathrm{D}_{3} 383 / 365 \text { (quant), } \\
383 / 257 \text { (qual); } 25(\mathrm{OH}) \mathrm{D}_{2} \\
395 / 377 \text { (quant), 395/209 } \\
\text { (qual) }\end{array}$ \\
\hline 212 & $25(\mathrm{OH}) \mathrm{D}_{3}-d_{6}$ & $\begin{array}{l}\text { Serum }(100 \mu \mathrm{L}) \text { precipitated with } \\
\text { 5:95 methanol:acetonitrile } \\
\text { containing the IS }(350 \mu \mathrm{L})\end{array}$ & $\begin{array}{l}\text { C8 column }(50 \times 2 \mathrm{~mm} ; 3 \mu \mathrm{m}) \\
\text { gradient starting with } 60 \% \\
\text { acetonitrile }(0.1 \% \text { formic acid), } 40 \% \\
\text { water }(0.1 \% \text { formic acid })\end{array}$ & $\begin{array}{l}25(\mathrm{OH}) \mathrm{D}_{3} 383 / 229,383 / 211 ; \\
25(\mathrm{OH}) \mathrm{D}_{3}-d_{6} 389 / 211 ; \\
25(\mathrm{OH}) \mathrm{D}_{2} 395 / 269,395 / 119\end{array}$ \\
\hline
\end{tabular}




\begin{tabular}{|c|c|c|c|c|}
\hline 215 & $25(\mathrm{OH}) \mathrm{D}_{3}-d_{6}$ & $\begin{array}{l}\text { Protein precipitation with } \\
\text { methanol/isopropanol and } \mathrm{ZnSO}_{4} \\
\text { supernatant extracted using solid } \\
\text { phase extraction }\end{array}$ & $\begin{array}{l}\text { C18 column }(50 \times 2.1 \mathrm{~mm} ; 2.6 \mu \mathrm{m}) \\
\text { column; gradient with water }(0.1 \% \\
\text { formic acid, } 5 \mathrm{mmol} / \mathrm{L} \text { ammonium } \\
\text { formate) and methanol }(0.05 \% \\
\text { formic acid) }\end{array}$ & $\begin{array}{l}25(\mathrm{OH}) \mathrm{D}_{3} 401 / 383 \\
25(\mathrm{OH}) \mathrm{D}_{2} 413 / 395 \\
25(\mathrm{OH}) \mathrm{D}_{3}-d_{6} 407 / 389\end{array}$ \\
\hline 216 & $\begin{array}{c}25(\mathrm{OH}) \mathrm{D}_{2}-d_{3} \text { and } \\
25(\mathrm{OH}) \mathrm{D}_{3}-d_{6}\end{array}$ & $\begin{array}{l}\text { Samples extracted using liquid- } \\
\text { liquid extraction then labeled with } \\
\text { a derivatization reagent }\end{array}$ & $\begin{array}{l}\text { C18 column }(200 \times 2.1 \mathrm{~mm}) \\
\text { gradient from } 25 \% \text { water }(0.05 \% \\
\text { formic acid) to } 50 \% \text { acetonitrile } \\
(0.05 \% \text { formic acid }) ; \text { flow } 0.2 \\
\mathrm{~mL} / \mathrm{min}\end{array}$ & $n / r$ \\
\hline 217 & $25(\mathrm{OH}) \mathrm{D}_{3}-d_{6}$ & $\begin{array}{l}\text { Protein precipitation with } \mathrm{ZnSO}_{4} \text { in } \\
\text { methanol followed by solid phase } \\
\text { extraction }\end{array}$ & $\begin{array}{l}\text { C8 column }(50 \times 2.1 \mathrm{~mm} ; 1.7 \mu \mathrm{m}) \text {; } \\
\text { gradient of } 70 \% \text { to } 98 \% \text { methanol } \\
\text { (with } 0.1 \% \text { formic acid); flow } 0.4 \\
\mathrm{~mL} / \mathrm{min}\end{array}$ & $\begin{array}{l}25(\mathrm{OH}) \mathrm{D}_{3} 401 / 159 \text { (quant), } \\
401 / 383 \text { (qual); } 25(\mathrm{OH}) \mathrm{D}_{2} \\
413 / 83 \text { (quant), } 413 / 395 \\
\text { (qual) }\end{array}$ \\
\hline $218 b$ & $\begin{array}{c}25(\mathrm{OH}) \mathrm{D}_{2}-d_{3} \text { and } \\
25(\mathrm{OH}) \mathrm{D}_{3}-d_{3}\end{array}$ & $\begin{array}{l}\text { Sample was extracted, filtered, } \\
\text { centrifuged, etc. }\end{array}$ & $\begin{array}{l}\text { Phenyl column }(50 \times 2.1 \mathrm{~mm} ; 1.7 \\
\mu \mathrm{m}) \text {; flow } 0.45 \mathrm{~mL} / \mathrm{min}\end{array}$ & $\begin{array}{l}25(\mathrm{OH}) \mathrm{D}_{3} 401 \\
25(\mathrm{OH}) \mathrm{D}_{2} 413\end{array}$ \\
\hline 219 & $25(\mathrm{OH}) \mathrm{D}_{3}-d_{6}$ & Online SPE & $\mathrm{n} / \mathrm{r}$ & $\mathrm{n} / \mathrm{r}$ \\
\hline 220 & $\begin{array}{c}25(\mathrm{OH}) \mathrm{D}_{2}-d_{3} \text { and } \\
25(\mathrm{OH}) \mathrm{D}_{3}-d_{6}\end{array}$ & $\begin{array}{l}\text { Protein crash with } 90 \% \text { methanol, } \\
10 \% \mathrm{ZnSO}_{4} \text { and then acetonitrile } \\
(1 \% \text { formic acid); sample filtered } \\
\text { then phospholipids removed with } \\
\text { solid phase extraction }\end{array}$ & $\begin{array}{l}\mathrm{C} 18 \text { column }(20 \times 2.1 \mathrm{~mm}, 2.7 \mu \mathrm{m}) \\
\text { gradient with water and acetonitrile; } \\
\text { flow } 1 \mathrm{~mL} / \mathrm{min} \text {; column } 40{ }^{\circ} \mathrm{C}\end{array}$ & $n / r$ \\
\hline $221 a$ & $25(\mathrm{OH}) \mathrm{D}_{3}-d_{6}$ & $\begin{array}{l}\text { Protein crash with } 1 \% \text { methanol in } \\
\text { acetonitrile containing IS }\end{array}$ & $\begin{array}{l}\mathrm{CN} \text { column }(50 \times 3.0 \mathrm{~mm} ; 1.8 \mu \mathrm{m}) \\
\text { methanol/water gradient at } 50^{\circ} \mathrm{C}\end{array}$ & $\begin{array}{l}25(\mathrm{OH}) \mathrm{D}_{3} 383 / 211 \\
25(\mathrm{OH}) \mathrm{D}_{3}-d_{6} 389 / 211 \\
25(\mathrm{OH}) \mathrm{D}_{2} 395 / 209\end{array}$ \\
\hline $228 a$ & $\mathrm{n} / \mathrm{r}$ & $\begin{array}{l}\text { Proteins precipitated followed by } \\
\text { centrifugation }\end{array}$ & $\begin{array}{l}\text { C18 column; gradient with water } \\
\text { and methanol }\end{array}$ & $\begin{array}{l}25(\mathrm{OH}) \mathrm{D}_{3} 401 \\
25(\mathrm{OH}) \mathrm{D}_{2} 413 \\
\end{array}$ \\
\hline 234 & $25(\mathrm{OH}) \mathrm{D}_{3}-d_{6}$ & $\begin{array}{l}\text { The samples are protein crashed } \\
\text { using acetonitrile }\end{array}$ & $\begin{array}{l}\text { A turbo column is used for cleanup } \\
\text { followed by a } \mathrm{C} 18 \text { analytical } \\
\text { column; isocratic separation with } \\
\text { water and methanol }\end{array}$ & $\begin{array}{l}25(\mathrm{OH}) \mathrm{D}_{3} 383 / 365 \\
25(\mathrm{OH}) \mathrm{D}_{2} 395 / 209 \\
25(\mathrm{OH}) \mathrm{D}_{3}-d_{6} 389 / 211\end{array}$ \\
\hline 241 & $25(\mathrm{OH}) \mathrm{D}_{3}-d_{6}$ & $\begin{array}{l}\text { Acetonitrile containing the IS ( } 100 \\
\mu \mathrm{L}) \text { added to sample }(50 \mu \mathrm{L}) \text { to } \\
\text { precipate proteins, followed by } \\
\text { mixing, sonication, and } \\
\text { centrifugation. }\end{array}$ & $\begin{array}{l}\text { C8 column }(50 \times 2 \mathrm{~mm} ; 3 \mu \mathrm{m}) \\
\text { gradient starting with } 50 \% \\
\text { methanol }(0.1 \% \text { formic acid }), 50 \% \\
\text { water }(0.1 \% \text { formic acid })\end{array}$ & $\begin{array}{l}25(\mathrm{OH}) \mathrm{D}_{3} 383 / 211 \text { (quant), } \\
383 / 229 \text { (qual); } 25(\mathrm{OH}) \mathrm{D}_{2} \\
395 / 119 \text { (quant), 395/211 } \\
\text { (qual); } 25(\mathrm{OH}) \mathrm{D}_{3}-d_{6} 389 / 211\end{array}$ \\
\hline 242 & $25(\mathrm{OH}) \mathrm{D}_{3}-d_{6}$ & $\begin{array}{l}\text { Ethanol containing the IS }(75 \mu \mathrm{L}) \\
\text { and acetonitrile }(500 \mu \mathrm{L}) \text { added to } \\
\text { sample }(400 \mu \mathrm{L}) \text { to precipate } \\
\text { proteins, followed by extraction } \\
\text { with heptane, evaporation, and } \\
\text { reconsitution in methanol. }\end{array}$ & $\begin{array}{l}\text { Reversed-phase column }(150 \times 2 \\
\mathrm{mm}) \text {; gradient with } \\
\text { acetonitrile/water; flow } 0.35 \mathrm{~mL} / \mathrm{min}\end{array}$ & $\begin{array}{l}25(\mathrm{OH}) \mathrm{D}_{3} 401 / 383 \\
25(\mathrm{OH}) \mathrm{D}_{2} 413 / 395 \\
25(\mathrm{OH}) \mathrm{D}_{3}-d_{6} 407 / 389\end{array}$ \\
\hline 244 & $25(\mathrm{OH}) \mathrm{D}_{3}-d_{6}$ & $\begin{array}{l}\text { Protein precipitation followed by } \\
\text { filtration }\end{array}$ & $\begin{array}{l}\text { CN column; mobile phase } \\
\text { consisting of distilled water (formic } \\
\text { acid) and methanol }\end{array}$ & $\begin{array}{l}25(\mathrm{OH}) \mathrm{D}_{2} 395 / 269 \\
25(\mathrm{OH}) \mathrm{D}_{3} 383 / 211\end{array}$ \\
\hline 248 & $\begin{array}{c}25(\mathrm{OH}) \mathrm{D}_{2}-d_{3} \text { and } \\
25(\mathrm{OH}) \mathrm{D}_{3}-d_{3}\end{array}$ & $\begin{array}{l}\text { IS was added and the sample was } \\
\text { precipitated with acetonitrile, } \\
\text { centrifuged, and injected }\end{array}$ & $\begin{array}{l}\mathrm{C} 18 \text { column }(100 \times 2.1 \mathrm{~mm} ; 2.5 \\
\mu \mathrm{m}) ; \text { gradient with water and } \\
\text { methanol, each containing } 2 \mathrm{mmol} / \mathrm{L} \\
\text { ammonium acetate }\end{array}$ & $\begin{array}{l}25(\mathrm{OH}) \mathrm{D}_{3} 383 / 257 \text { (quant), } \\
383 / 365 \text { (qual); } 25(\mathrm{OH}) \mathrm{D}_{2} \\
395 / 377 \text { (quant), 395/269 } \\
\text { (qual); } 25(\mathrm{OH}) \mathrm{D}_{3}-d_{3} 386 / 257 \\
\text { (quant), 386/368 (qual); } \\
25(\mathrm{OH}) \mathrm{D}_{2}-\mathrm{d}_{3} 398 / 380 \\
\text { (quant), 398/271 (qual) }\end{array}$ \\
\hline 249 & $\begin{array}{c}25(\mathrm{OH}) \mathrm{D}_{2}-d_{3} \text { and } \\
25(\mathrm{OH}) \mathrm{D}_{3}-d_{6}\end{array}$ & $\begin{array}{l}\text { Proteins precipitated followed by } \\
\text { centrifugation and SPE }\end{array}$ & $\begin{array}{l}\text { PFP column ( } 100 \times 2.1 \mathrm{~mm} ; 1.8 \\
\mu \mathrm{m}) ; \text { gradient separation with water } \\
(2 \mathrm{mmol} / \mathrm{L} \text { ammonium acetate, } 0.1 \% \\
\text { formic acid) and methanol }(0.3 \% \\
\text { formic acid); flow } 0.3 \mathrm{~mL} / \mathrm{min}\end{array}$ & $\begin{array}{l}25(\mathrm{OH}) \mathrm{D}_{3} 401 / 159 \\
25(\mathrm{OH}) \mathrm{D}_{3}-d_{6} 407 / 159 \\
25(\mathrm{OH}) \mathrm{D}_{2} 413 / 159 \\
25(\mathrm{OH}) \mathrm{D}_{2}-d_{3} 416 / 83\end{array}$ \\
\hline
\end{tabular}




\begin{tabular}{|c|c|c|c|c|}
\hline 250 & $\begin{array}{c}25(\mathrm{OH}) \mathrm{D}_{2}-d_{3} \text { and } \\
25(\mathrm{OH}) \mathrm{D}_{3}-d_{3}\end{array}$ & Protein crash followed by SPE & $\begin{array}{l}\text { Phenyl column }(50 \times 2.1 \mathrm{~mm}) \text {; } \\
\text { gradient with water and methanol, } \\
\text { each containing } 2 \mathrm{mmol} / \mathrm{L} \\
\text { ammonium acetate and } 0.1 \% \text { formic } \\
\text { acid; flow } 0.45 \mathrm{~mL} / \mathrm{min}\end{array}$ & $\begin{array}{l}25(\mathrm{OH}) \mathrm{D}_{3} 401 / 159,401 / 365 \\
25(\mathrm{OH}) \mathrm{D}_{2} 413 / 355,413 / 83\end{array}$ \\
\hline 251 & $\begin{array}{l}25(\mathrm{OH}) \mathrm{D}_{2}-d_{3} \text { and } \\
25(\mathrm{OH}) \mathrm{D}_{3}-d_{3}\end{array}$ & $\begin{array}{l}\text { Protein precipitation followed by } \\
\text { SPE }\end{array}$ & $\begin{array}{l}\text { Phenyl column }(50 \times 2.1 \mathrm{~mm} ; 1.7 \\
\mu \mathrm{m}) \text {; gradient with water and } \\
\text { methanol, each containing } 2 \mathrm{mmol} / \mathrm{L} \\
\text { ammonium acetate and } 0.1 \% \text { formic } \\
\text { acid; flow } 0.45 \mathrm{~mL} / \mathrm{min}\end{array}$ & $\begin{array}{l}25(\mathrm{OH}) \mathrm{D}_{3} 401 / 159 \text { (quant), } \\
401 / 365 \text { (qual); } 25(\mathrm{OH}) \mathrm{D}_{2} \\
413 / 355 \text { (quant), } 413 / 83 \\
\text { (qual); } 25(\mathrm{OH}) \mathrm{D}_{3}-d_{3} \\
\text { 404/162; } 25(\mathrm{OH}) \mathrm{D}_{2}-\mathrm{d}_{3} \\
\text { 416/358 }\end{array}$ \\
\hline 253 & $d$-labeled isotope & $\begin{array}{l}\text { The sample was extracted with } \\
\text { acetonitrile/trifluroacetic acid and } \\
\text { then centrifuged }\end{array}$ & $\begin{array}{l}\text { C18 column }(50 \times 2.1 \mathrm{~mm}) \text {; isocratic } \\
\text { separation with water and methanol; } \\
\text { flow } 0.4 \mathrm{~mL} / \mathrm{min}\end{array}$ & $\begin{array}{l}25(\mathrm{OH}) \mathrm{D}_{2} 619 / 298 \\
25(\mathrm{OH}) \mathrm{D}_{3} 607 / 298\end{array}$ \\
\hline
\end{tabular}

MRM = multiple reaction monitoring

$\mathrm{PFP}=$ pentafluorophenyl

$\mathrm{n} / \mathrm{r}=$ not reported

quant $=$ quantitative ions

qual $=$ qualitative ions

$\mathrm{SPE}=$ solid phase extraction

$\mathrm{CN}=$ cyano 
Appendix A-3. Summary of LC-UV methods used by participants.

\begin{tabular}{|c|c|c|c|c|}
\hline $\begin{array}{l}\text { Laboratory } \\
\text { Number }\end{array}$ & $\begin{array}{c}\text { Internal } \\
\text { Standard (IS) }\end{array}$ & Sample Preparation & Chromatographic Conditions & Wavelength \\
\hline 110 & $\mathrm{n} / \mathrm{r}$ & $\begin{array}{l}\text { Samples were extracted twice with } \\
\text { hexane/methylene chloride }(5: 1) \text {, } \\
\text { evaporated and reconstituted }\end{array}$ & $\begin{array}{l}\text { Ultra-fast LC; gradient with } \\
\text { acetonitrile/methanol }(85: 15) \text { and } \\
\text { isopropanol }(100 \%)\end{array}$ & $268 \mathrm{~nm}$ \\
\hline 139 & Proprietary & $\begin{array}{l}\text { The sample was extracted, } \\
\text { centrifuged and injected }\end{array}$ & $\begin{array}{l}\text { Reversed-phase column, isocratic } \\
\text { separation with proprietary mobile } \\
\text { phase; flow } 1 \mathrm{~mL} / \mathrm{min}\end{array}$ & $264 \mathrm{~nm}$ \\
\hline 189 & $\begin{array}{l}\text { Added before } \\
\text { extraction }\end{array}$ & $\begin{array}{l}\text { Proteins were disrupted and } \\
\text { precipitated; analytes were } \\
\text { extracted using solid-phase } \\
\text { extraction }\end{array}$ & $\begin{array}{l}\text { Reversed-phase column }(150 \times 4.6 \\
\mathrm{mm}) \text {; isocratic separation with } \\
\text { commercial mobile phase; flow } \\
0.7 \mathrm{~mL} / \mathrm{min}\end{array}$ & $265 \mathrm{~nm}$ \\
\hline $221 b$ & Laurophenone & $\begin{array}{l}\text { Protein crash with acetonitrile } \\
\text { (contaning IS), followed by } \\
\text { extraction on C-18 sorbent, } \\
\text { elution with methanol/acetonitrile, } \\
\text { evaporation, and reconstitution } \\
\text { with acetonitrile }\end{array}$ & $\begin{array}{l}\mathrm{CN} \text { column }(150 \times 4.6 \mathrm{~mm} ; 3.5 \mu \mathrm{m}) \text {; } \\
\text { methanol/water/formic acid mobile } \\
\text { phase; } 47^{\circ} \mathrm{C}\end{array}$ & $275 \mathrm{~nm}$ \\
\hline 231 & 1alpha $(\mathrm{OH}) \mathrm{D}_{3}$ & $\begin{array}{l}\text { Samples were extracted with } \\
\text { hexane/dichloromethane, } \\
\text { evaporated and reconstituted with } \\
\text { mobile phase (phosphate } \\
\text { buffer/acetonitrile) }\end{array}$ & $\begin{array}{l}\text { Reversed-phase column }(250 \times 4.5 \\
\mathrm{mm} ; 5 \mu \mathrm{m}) \text {, isocratic separation with } \\
14 \% \text { phosphate buffer, } 86 \% \\
\text { acetonitrile; flow } 1.2 \mathrm{~mL} / \mathrm{min}\end{array}$ & $265 \mathrm{~nm}$ \\
\hline 243 & Laurophenone & $\begin{array}{l}\text { Reagent } 1 \text { containing the } \\
\text { ethanolic IS }(400 \mu \mathrm{L}) \text { added to } \\
\text { sample }(400 \mu \mathrm{L}), \text { followed by } \\
\text { vortexing the precipitation reagent } \\
(500 \mu \mathrm{L}) \text { and sampling of the } \\
\text { supernatant }\end{array}$ & $\begin{array}{l}\text { Reversed-phase column }(150 \times 3 \\
\mathrm{mm}) \text {; isocratic separation with } 65 \% \\
\text { acetonitrile, } 35 \% \text { water; flow } 1 \\
\mathrm{~mL} / \mathrm{min}\end{array}$ & $264 \mathrm{~nm}$ \\
\hline
\end{tabular}

$\mathrm{n} / \mathrm{r}=$ not reported

$\mathrm{CN}=$ cyano 
Appendix B-1. Raw participant data and NIST results for 25(OH)D $\mathrm{D}_{2}, 25(\mathrm{OH}) \mathrm{D}_{3}$ and $25(\mathrm{OH}) \mathrm{D}_{\text {Total }}$ in SRM 972a L1, SRM 972a L3,and SRM 968d L1 and the control solutions, SRM 2972.

\begin{tabular}{|c|c|c|c|c|c|c|c|c|c|c|c|c|c|c|c|}
\hline & & & & & & & & & & & & & & \multirow{3}{*}{\multicolumn{2}{|c|}{$\begin{array}{c}25(\mathrm{OH}) \mathrm{D}_{2} / \mathrm{D}_{3}(\mathrm{ng} / \mathrm{mL}) \\
\mathrm{SRM} 2972 \\
\end{array}$}} \\
\hline & \multirow{3}{*}{ Method } & \multicolumn{4}{|c|}{$25(\mathrm{OH}) \mathrm{D}_{2}(\mathrm{ng} / \mathrm{mL})$} & \multicolumn{4}{|c|}{$25(\mathrm{OH}) \mathrm{D}_{3}(\mathrm{ng} / \mathrm{mL})$} & \multicolumn{4}{|c|}{$25(\mathrm{OH}) \mathrm{D}_{\text {Total }}(\mathrm{ng} / \mathrm{mL})$} & & \\
\hline & & \multirow{2}{*}{$\frac{\text { SRM 972a L1 }}{\text { Vial A }}$} & \multirow{2}{*}{\begin{tabular}{c|} 
SRM 972a L3 \\
Vial B
\end{tabular}} & \multirow{2}{*}{$\begin{array}{c}\text { SRM 968d L1 } \\
\text { Vial C } \\
\end{array}$} & \multirow{2}{*}{$\frac{\text { SRM 968d L1 }}{\text { Vial D }}$} & \multirow{2}{*}{\begin{tabular}{|c} 
SRM 972a L1 \\
Vial A
\end{tabular}} & & SRM 968d L1 & SRM 968d L1 & SRM 972a L1 & SRM 972a L3 & SRM 968d L1 & SRM 968d L1 & & \\
\hline Lab & & & & & & & Vial B & \begin{tabular}{|l|} 
Vial C \\
\end{tabular} & \begin{tabular}{|l|} 
Vial D \\
\end{tabular} & \begin{tabular}{|l|} 
Vial A \\
\end{tabular} & \begin{tabular}{l|l} 
Vial B \\
\end{tabular} & \begin{tabular}{|l|} 
Vial C \\
\end{tabular} & \begin{tabular}{|l|} 
Vial D \\
\end{tabular} & $25(\mathrm{OH}) \mathrm{D}_{2}$ & \\
\hline 017 & CLIA & $\mathrm{n} / \mathrm{a}$ & $\mathrm{n} / \mathrm{a}$ & \begin{tabular}{|l|}
$\mathrm{n} / \mathrm{a}$ \\
\end{tabular} & $\mathrm{n} / \mathrm{a}$ & \begin{tabular}{|l|}
$\mathrm{n} / \mathrm{a}$ \\
\end{tabular} & n/a & $\mathrm{n} / \mathrm{a}$ & $n / a$ & 28.1 & 27.7 & 14.0 & 14.7 & $n / r$ & $\mathrm{n} / \mathrm{r}$ \\
\hline 026 & LC-MS/MS & $<1.0$ & 13.4 & $<1.0$ & $<1.0$ & 31.0 & 20.1 & 12.7 & 13.4 & 31.0 & 33.5 & 12.7 & 13.4 & $n / r$ & $n / r$ \\
\hline 030 & RIA & $\mathrm{n} / \mathrm{a}$ & $\mathrm{n} / \mathrm{a}$ & $n / a$ & $\mathrm{n} / \mathrm{a}$ & $\mathrm{n} / \mathrm{a}$ & $\mathrm{n} / \mathrm{a}$ & $\mathrm{n} / \mathrm{a}$ & $\mathrm{n} / \mathrm{a}$ & 32.4 & 26.7 & 15.8 & 14.4 & 257.0 & 408.5 \\
\hline 056 & LC-MS/MS & 0.7 & 14.7 & n/d & n/d & 30.2 & 20.1 & 12.6 & 12.3 & 30.9 & 34.8 & 12.6 & 12.3 & 246.7 & 346.3 \\
\hline 060 & LC-MS/MS & $<2.00$ & 17.3 & $\mathrm{n} / \mathrm{d}$ & $\mathrm{n} / \mathrm{d}$ & 37.1 & 24.9 & 15.3 & 14.6 & 37.1 & 42.2 & 15.3 & 14.6 & 210.1 & 348.1 \\
\hline $086 a$ & CLIA & $\mathrm{n} / \mathrm{a}$ & $\mathrm{n} / \mathrm{a}$ & $\mathrm{n} / \mathrm{a}$ & $\mathrm{n} / \mathrm{a}$ & $\mathrm{n} / \mathrm{a}$ & $\mathrm{n} / \mathrm{a}$ & $\mathrm{n} / \mathrm{a}$ & $\mathrm{n} / \mathrm{a}$ & 27.4 & 26.8 & 14.4 & 15.7 & $\mathrm{n} / \mathrm{r}$ & $\mathrm{n} / \mathrm{r}$ \\
\hline 086b & RIA & $\mathrm{n} / \mathrm{a}$ & $n / a$ & $\mathrm{n} / \mathrm{a}$ & $n / a$ & $\mathrm{n} / \mathrm{a}$ & $\mathrm{n} / \mathrm{a}$ & $\mathrm{n} / \mathrm{a}$ & $\mathrm{n} / \mathrm{a}$ & 32.0 & 40.0 & 17.0 & 17.0 & $n / r$ & $\mathrm{n} / \mathrm{r}$ \\
\hline 110 & LC-UV & $<4$ & $<4$ & $<4$ & $<4$ & 19.9 & 23.3 & 14.3 & 15.3 & 21.5 & 23.3 & 14.3 & 17.9 & 239.2 & 335.2 \\
\hline 116 & LC-MS/MS & $<3.3$ & 15.5 & $<3.3$ & $<3.3$ & 35.1 & 22.4 & 15.4 & 15.5 & 35.1 & 37.9 & 15.4 & 15.5 & $\mathrm{n} / \mathrm{r}$ & $\mathrm{n} / \mathrm{r}$ \\
\hline 128 & LC-MS/MS & $n / r$ & $\mathrm{n} / \mathrm{r}$ & $\mathrm{n} / \mathrm{r}$ & $\mathrm{n} / \mathrm{r}$ & 37.0 & 24.1 & 15.6 & 14.1 & 37.0 & 24.1 & 15.6 & 14.1 & $\mathrm{n} / \mathrm{r}$ & 332.0 \\
\hline 139 & LC-UV & $\mathrm{n} / \mathrm{d}$ & 12.2 & $n / d$ & $\mathrm{n} / \mathrm{d}$ & 32.0 & 22.5 & 13.0 & 13.6 & 32.0 & 34.7 & 13.0 & 13.6 & 256.0 & 335.0 \\
\hline 180 & RIA & $n / a$ & $\mathrm{n} / \mathrm{a}$ & $\mathrm{n} / \mathrm{a}$ & $\mathrm{n} / \mathrm{a}$ & $\mathrm{n} / \mathrm{a}$ & $\mathrm{n} / \mathrm{a}$ & $\mathrm{n} / \mathrm{a}$ & $\mathrm{n} / \mathrm{a}$ & 32.8 & 34.8 & 13.7 & 16.0 & $\mathrm{n} / \mathrm{r}$ & $\mathrm{n} / \mathrm{r}$ \\
\hline 183b & CLIA & $\mathrm{n} / \mathrm{a}$ & $\mathrm{n} / \mathrm{a}$ & $\mathrm{n} / \mathrm{a}$ & $\mathrm{n} / \mathrm{a}$ & n/a & $\mathrm{n} / \mathrm{a}$ & $\mathrm{n} / \mathrm{a}$ & $\mathrm{n} / \mathrm{a}$ & 28.0 & 25.0 & 13.8 & 13.9 & 262.4 & 336.8 \\
\hline 185a & LC-MS/MS & $\mathrm{n} / \mathrm{d}$ & 17.2 & 2.1 & $n / d$ & 32.1 & 20.8 & 12.3 & 12.3 & 32.1 & 38.0 & 14.4 & 12.3 & 238.6 & 334.8 \\
\hline 187 & LC-MS/MS & $\mathrm{n} / \mathrm{d}$ & 12.5 & $n / d$ & $\mathrm{n} / \mathrm{d}$ & 32.7 & 20.6 & 13.1 & 12.9 & 32.7 & 33.1 & 13.1 & 12.9 & $\mathrm{n} / \mathrm{r}$ & $\mathrm{n} / \mathrm{r}$ \\
\hline 188 & CLIA & $\mathrm{n} / \mathrm{a}$ & $\mathrm{n} / \mathrm{a}$ & $\mathrm{n} / \mathrm{a}$ & $\mathrm{n} / \mathrm{a}$ & $\mathrm{n} / \mathrm{a}$ & $\mathrm{n} / \mathrm{a}$ & $\mathrm{n} / \mathrm{a}$ & $\mathrm{n} / \mathrm{a}$ & 31.4 & 29.4 & 12.9 & 14.1 & $\mathrm{n} / \mathrm{r}$ & $\mathrm{n} / \mathrm{r}$ \\
\hline 189 & LC-UV & $\mathrm{n} / \mathrm{d}$ & $\mathrm{n} / \mathrm{d}$ & $\mathrm{n} / \mathrm{d}$ & $\mathrm{n} / \mathrm{d}$ & 37.7 & 14.0 & 12.0 & 10.4 & 37.7 & 14.0 & 12.0 & 10.4 & $n / r$ & n/r \\
\hline 194 & LC-MS/MS & $<7$ & 14.1 & $<7$ & $<7$ & 32.3 & 20.0 & 12.9 & 13.1 & 32.3 & 34.1 & 12.9 & 13.1 & 240.5 & 335.0 \\
\hline 196 & CLIA & n/a & n/a & $\mathrm{n} / \mathrm{a}$ & $\mathrm{n} / \mathrm{a}$ & $\mathrm{n} / \mathrm{a}$ & n/a & $\mathrm{n} / \mathrm{a}$ & n/a & 31.6 & 29.2 & 14.5 & 15.6 & n/r & $n / r$ \\
\hline 197 & LC-MS/MS & $<5$ & 15.0 & $<5$ & $<5$ & 32.0 & 21.3 & 13.8 & 14.3 & 32.0 & 36.3 & 13.8 & 14.3 & 238.0 & 343.0 \\
\hline 198a & LC-MS/MS & $<5$ & 12.5 & $<5$ & $<5$ & 29.8 & 18.7 & 12.9 & 15.2 & 29.8 & 31.2 & 12.9 & 15.2 & 228.2 & 324.1 \\
\hline $\begin{array}{l}198 \mathrm{~b} \\
199\end{array}$ & EIA & $\begin{array}{l}\mathrm{n} / \mathrm{a} \\
<2\end{array}$ & $\begin{array}{l}\mathrm{n} / \mathrm{a} \\
1332\end{array}$ & $\begin{array}{l}n / a \\
<2\end{array}$ & $\begin{array}{l}n / \mathrm{a} \\
<2\end{array}$ & $\begin{array}{c}\mathrm{n} / \mathrm{a} \\
307\end{array}$ & $\begin{array}{l}\mathrm{n} / \mathrm{a} \\
20.5\end{array}$ & $\begin{array}{l}\mathrm{n} / \mathrm{a} \\
127\end{array}$ & $\begin{array}{l}\mathrm{n} / \mathrm{a} \\
126\end{array}$ & $\begin{array}{l}28.2 \\
307\end{array}$ & $\begin{array}{l}27.6 \\
337\end{array}$ & $\begin{array}{l}12.2 \\
12.2\end{array}$ & $\begin{array}{l}14.1 \\
12.6\end{array}$ & $\begin{array}{c}n / r \\
2494\end{array}$ & $\begin{array}{r}n / r \\
329.9\end{array}$ \\
\hline $\begin{array}{l}199 \\
202\end{array}$ & $\begin{array}{l}\text { LC-MSIMS } \\
\text { LC-MS/MS }\end{array}$ & $\begin{array}{l}<2 \\
\mathrm{n} / \mathrm{d}\end{array}$ & $\begin{array}{l}13.2 \\
13.5\end{array}$ & $\begin{array}{l}<2 \\
\mathrm{n} / \mathrm{d}\end{array}$ & $\begin{array}{l}<2 \\
\text { n/d }\end{array}$ & $\begin{array}{l}30.7 \\
33.4\end{array}$ & $\begin{array}{l}20.5 \\
218\end{array}$ & $\begin{array}{l}12.7 \\
12.9\end{array}$ & $\begin{array}{l}12.6 \\
12.7\end{array}$ & $\begin{array}{l}30.7 \\
33.4\end{array}$ & $\begin{array}{l}33.7 \\
35.3\end{array}$ & $\begin{array}{l}12.7 \\
12.9\end{array}$ & $\begin{array}{l}12.6 \\
127\end{array}$ & 249.4 & 329.9 \\
\hline 209 & $\begin{array}{l}\text { LC-MSSMS } \\
\text { LCMS/MS }\end{array}$ & $\begin{array}{l}\mathrm{n} / \mathrm{d} \\
<10\end{array}$ & $\begin{array}{l}13.5 \\
15.3\end{array}$ & $\begin{array}{l}\text { n/d } \\
<10\end{array}$ & $\begin{array}{l}\text { n/d } \\
<10\end{array}$ & $\begin{array}{l}33.4 \\
31.7\end{array}$ & $\begin{array}{l}21.8 \\
24.3\end{array}$ & $\begin{array}{l}12.9 \\
11.9\end{array}$ & $\begin{array}{l}12.7 \\
128\end{array}$ & $\begin{array}{l}33.4 \\
31.7\end{array}$ & $\begin{array}{l}35.3 \\
39.6\end{array}$ & 12.9 & $\begin{array}{l}12.7 \\
128\end{array}$ & 246.0 & 345.0 \\
\hline $210 \mathrm{a}$ & RIA & $\mathrm{n} / \mathrm{a}$ & $\mathrm{n} / \mathrm{a}$ & $\begin{array}{l}\mathrm{n} / \mathrm{a} \\
\text { a }\end{array}$ & $\begin{array}{l}\mathrm{n} / \mathrm{a} \\
\mathrm{n}\end{array}$ & $\mathrm{n} / \mathrm{a}$ & $\begin{array}{l}4.3 \\
\mathrm{n} / \mathrm{a}\end{array}$ & $\mathrm{n} / \mathrm{a}$ & $\begin{array}{l}12.8 \\
\mathrm{n} / \mathrm{a}\end{array}$ & $\begin{array}{l}31.1 \\
31.4\end{array}$ & $\begin{array}{l}39.6 \\
31.3\end{array}$ & $\begin{array}{l}11.9 \\
12.6\end{array}$ & $\begin{array}{l}12.8 \\
12.8\end{array}$ & $\begin{array}{l}n=1 / r \\
n / r\end{array}$ & $\begin{array}{l}n \pi / r \\
n / r\end{array}$ \\
\hline $210 \mathrm{~b}$ & CLIA & $\mathrm{n} / \mathrm{a}$ & $\mathrm{n} / \mathrm{a}$ & $n / a$ & $\mathrm{n} / \mathrm{a}$ & $\mathrm{n} / \mathrm{a}$ & $\mathrm{n} / \mathrm{a}$ & $\mathrm{n} / \mathrm{a}$ & $n / a$ & 26.8 & 26.4 & 13.2 & 13.7 & $\mathrm{n} / \mathrm{r}$ & $\mathrm{n} / \mathrm{r}$ \\
\hline 211 & LC-MS/MS & $\mathrm{n} / \mathrm{d}$ & 14.1 & $\mathrm{n} / \mathrm{d}$ & $\mathrm{n} / \mathrm{d}$ & 31.5 & 20.0 & 12.3 & 11.7 & 31.5 & 34.1 & 12.3 & 11.7 & 229.0 & 280.0 \\
\hline 212 & LC-MS/MS & $\mathrm{n} / \mathrm{d}$ & 22.4 & $n / d$ & n/d & 35.4 & 21.8 & 14.7 & 15.1 & 35.4 & 44.2 & 14.7 & 15.1 & $\mathrm{n} / \mathrm{r}$ & $\mathrm{n} / \mathrm{r}$ \\
\hline $213 a$ & CLIA & $\mathrm{n} / \mathrm{a}$ & $\mathrm{n} / \mathrm{a}$ & $\mathrm{n} / \mathrm{a}$ & $n / a$ & $\mathrm{n} / \mathrm{a}$ & $\mathrm{n} / \mathrm{a}$ & $\mathrm{n} / \mathrm{a}$ & $\mathrm{n} / \mathrm{a}$ & 27.5 & 25.0 & 3.7 & 3.7 & $n / r$ & $n / r$ \\
\hline $213 \mathrm{~b}$ & EIA & $\mathrm{n} / \mathrm{a}$ & $\mathrm{n} / \mathrm{a}$ & $\mathrm{n} / \mathrm{a}$ & $n / a$ & n/a & $\mathrm{n} / \mathrm{a}$ & n/a & $\mathrm{n} / \mathrm{a}$ & 28.2 & 23.8 & 12.9 & 12.2 & $n / r$ & $\mathrm{n} / \mathrm{r}$ \\
\hline 215 & LC-MS/MS & 0.4 & 12.0 & $\mathrm{n} / \mathrm{d}$ & $\mathrm{n} / \mathrm{d}$ & 32.0 & 20.4 & 12.0 & 13.6 & 32.4 & 32.4 & 12.0 & 13.6 & $n / r$ & $\mathrm{n} / \mathrm{r}$ \\
\hline 216 & LC-MS/MS & 0.5 & 13.7 & 0.2 & 0.2 & 30.0 & 19.7 & 13.0 & 12.6 & 30.5 & 33.4 & 13.2 & 12.8 & 229.9 & 343.3 \\
\hline 217 & LC-MS/MS & $<2$ & 14.1 & $<2$ & $<2$ & 30.5 & 20.0 & 12.4 & 12.6 & 30.5 & 34.1 & 12.4 & 12.6 & $\mathrm{n} / \mathrm{r}$ & $\mathrm{n} / \mathrm{r}$ \\
\hline 218a & CLIA & n/a & $\mathrm{n} / \mathrm{a}$ & n/a & n/a & n/a & $\mathrm{n} / \mathrm{a}$ & $\mathrm{n} / \mathrm{a}$ & $\mathrm{n} / \mathrm{a}$ & 29.8 & 29.2 & 13.7 & 14.7 & $\mathrm{n} / \mathrm{r}$ & $\mathrm{n} / \mathrm{r}$ \\
\hline $\begin{array}{l}218 \mathrm{~b} \\
219\end{array}$ & LC-MSIMS & n/d & $\begin{array}{l}16.7 \\
127\end{array}$ & $\begin{array}{l}n / d \\
<40\end{array}$ & n/d & $\begin{array}{l}30.4 \\
300\end{array}$ & $\begin{array}{l}24.3 \\
20.9\end{array}$ & $\begin{array}{l}14.2 \\
12.4\end{array}$ & $\begin{array}{l}14.5 \\
127\end{array}$ & $\begin{array}{l}30.4 \\
300\end{array}$ & $\begin{array}{l}41.0 \\
336\end{array}$ & $\begin{array}{l}14.2 \\
124\end{array}$ & $\begin{array}{l}14.5 \\
12.5\end{array}$ & 239.1 & 336.0 \\
\hline 219 & LC-MS/MS & $<4.0$ & 12.7 & $<4.0$ & $<4.0$ & 30.0 & 20.9 & 12.4 & 12.7 & 30.0 & 33.6 & 12.4 & 12.7 & $\mathrm{n} / \mathrm{r}$ & $\mathrm{n} / \mathrm{r}$ \\
\hline 220 & LC-MS/MS & $<5$ & 14.0 & $<5$ & $<5$ & 35.0 & 23.0 & 14.0 & 14.0 & 35.0 & 37.0 & 14.0 & 14.0 & $n / r$ & $\mathrm{n} / \mathrm{r}$ \\
\hline 221a & LC-MS/MS & $\mathrm{n} / \mathrm{d}$ & 12.4 & $\mathrm{n} / \mathrm{d}$ & $\mathrm{n} / \mathrm{d}$ & 27.9 & 18.6 & 11.6 & 12.9 & 27.9 & 31.0 & 11.6 & 12.9 & $n / r$ & $\mathrm{n} / \mathrm{r}$ \\
\hline $221 \mathrm{~b}$ & LC-UV & $\mathrm{n} / \mathrm{d}$ & 11.1 & $\mathrm{n} / \mathrm{d}$ & $\mathrm{n} / \mathrm{d}$ & 24.4 & 16.9 & 25.0 & 24.7 & 24.4 & 28.0 & $\begin{array}{l}25.0 \\
\end{array}$ & 24.7 & $n / r$ & $\mathrm{n} / \mathrm{r}$ \\
\hline $\begin{array}{l}222 \\
228 \mathrm{a}\end{array}$ & CLIA & n/a & $\begin{array}{c}\mathrm{n} / \mathrm{a} \\
208\end{array}$ & $\begin{array}{l}n / a \\
n / d\end{array}$ & $\begin{array}{l}n / a \\
n / d\end{array}$ & $\begin{array}{c}\mathrm{n} / \mathrm{a} \\
45 \mathrm{2}\end{array}$ & $\begin{array}{l}\mathrm{n} / \mathrm{a} \\
30\end{array}$ & n/a & n/a & 33.1 & 35.3 & 13.5 & 12.3 & $n^{n / r}$ & $\begin{array}{l}\mathrm{n} / \mathrm{r} \\
3215\end{array}$ \\
\hline $228 \mathrm{a}$ & LC-MSIMS & n/d & 20.8 & n/d & n/d & 45.2 & 30.6 & $\begin{array}{l}17.3 \\
0.9\end{array}$ & 17.9 & $\begin{array}{l}45.2 \\
30.2\end{array}$ & 51.4 & $\begin{array}{l}17.3 \\
32\end{array}$ & $\begin{array}{c}17.9 \\
31\end{array}$ & 217.3 & 331.5 \\
\hline 2286 & $\begin{array}{l}\text { CLIA } \\
\text { LC-UY }\end{array}$ & $\begin{array}{l}n \text { na } \\
n / d\end{array}$ & $\begin{array}{l}\mathrm{n} / \mathrm{a} \\
15.6\end{array}$ & $\begin{array}{l}n / a \\
n / d\end{array}$ & $\begin{array}{l}\mathrm{n} / \mathrm{a} \\
\mathrm{n} / \mathrm{d}\end{array}$ & n/a & n/a & $\begin{array}{l}\mathrm{n} / \mathrm{a} \\
\end{array}$ & n/a & 30.5 & $\begin{array}{l}26.7 \\
36.9\end{array}$ & 3.2 & $\begin{array}{l}3.1 \\
140\end{array}$ & $\begin{array}{l}n / r \\
2453\end{array}$ & $\begin{array}{c}\mathrm{n} / \mathrm{r} \\
2045\end{array}$ \\
\hline $\begin{array}{l}231 \\
234\end{array}$ & $\begin{array}{l}\text { LC-UV } \\
\text { LC-MS/MS }\end{array}$ & $\begin{array}{l}\mathrm{n} / \mathrm{d} \\
<30\end{array}$ & $\begin{array}{l}15.6 \\
18.9\end{array}$ & 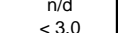 & $\begin{array}{l}\mathrm{n} / \mathrm{d} \\
<30\end{array}$ & $\begin{array}{l}26.6 \\
34.5\end{array}$ & $\begin{array}{l}21.3 \\
20.3\end{array}$ & $\begin{array}{l}14.8 \\
13.4\end{array}$ & $\begin{array}{l}14.0 \\
14.7\end{array}$ & $\begin{array}{l}26.6 \\
34.5\end{array}$ & $\begin{array}{l}36.9 \\
39.2\end{array}$ & $\begin{array}{l}14.8 \\
13.4\end{array}$ & $\begin{array}{l}14.0 \\
14.7\end{array}$ & 245.3 & 294.5 \\
\hline 241 & LC-MS/MS & $\mathrm{n} / \mathrm{d}$ & 13.3 & n/d & $n / d$ & $\begin{array}{l}\begin{array}{r}34.5 \\
30.5\end{array} \\
3\end{array}$ & 20.4 & $\begin{array}{l}13.4 \\
13.2\end{array}$ & $\begin{array}{l}12.7 \\
12.6\end{array}$ & $\begin{array}{l}34.5 \\
30.5\end{array}$ & $\begin{array}{l}39.2 \\
33.7\end{array}$ & $\begin{array}{l}13.4 \\
13.2\end{array}$ & $\begin{array}{l}14.7 \\
12.6\end{array}$ & $\begin{array}{l}n / r \\
n / r\end{array}$ & $\begin{array}{l}\mathrm{n} / \mathrm{r} \\
\mathrm{n} / \mathrm{r}\end{array}$ \\
\hline 242 & LC-MS/MS & $\mathrm{n} / \mathrm{d}$ & 17.9 & $\mathrm{n} / \mathrm{d}$ & n/d & 28.9 & 19.9 & 13.4 & 12.4 & 28.9 & 37.8 & 13.4 & 12.4 & 239.4 & 333.4 \\
\hline 243 & LC-UV & $\mathrm{n} / \mathrm{d}$ & 18.6 & $\mathrm{n} / \mathrm{d}$ & $\mathrm{n} / \mathrm{d}$ & 30.1 & 20.2 & 13.6 & 12.3 & 30.1 & 38.8 & 13.6 & 12.3 & 240.6 & 331.7 \\
\hline 244 & LC-MS/MS & $<5$ & 13.0 & $<5$ & $<5$ & 29.0 & 21.0 & 12.0 & 11.0 & 29.0 & 34. & 12.0 & 11.0 & 215.0 & 331.0 \\
\hline $247 a$ & CLIA & $n / a$ & $\mathrm{n} / \mathrm{a}$ & n/a & n/a & $\mathrm{n} / \mathrm{a}$ & $\mathrm{n} / \mathrm{a}$ & $\mathrm{n} / \mathrm{a}$ & $\mathrm{n} / \mathrm{a}$ & 38.1 & 37. & 17.7 & 14.2 & $n / r$ & $\mathrm{n} / \mathrm{r}$ \\
\hline $247 \mathrm{~b}$ & EIA & $n / a$ & $\mathrm{n} / \mathrm{a}$ & $n / a$ & n/a & n/a & n/a & n/a & $\mathrm{n} / \mathrm{a}$ & 31.3 & 30. & 16. & 16. & $n / r$ & $\mathrm{n} / \mathrm{r}$ \\
\hline 248 & LC-MS/MS & $<3$ & 16 & $<3$ & $<3$ & 31.7 & 24.4 & 14.0 & 14.2 & 31.7 & 41. & 14. & 14. & 238.6 & 334.8 \\
\hline 249 & LC-MS/MS & $\mathrm{n} / \mathrm{d}$ & 15 & $\mathrm{n} / \mathrm{d}$ & $\mathrm{n} / \mathrm{d}$ & 30.0 & 19.1 & 13.7 & 11.4 & 30. & 35. & 13. & 11. & 238.4 & 324.2 \\
\hline 250 & LC-MS/MS & $<2.4$ & 16.4 & $<2.4$ & $<2.4$ & 37.0 & 22.8 & 13.1 & 15.2 & 37.0 & 39.2 & 13.1 & 15.2 & 281.6 & 382.0 \\
\hline $\begin{array}{l}251 \\
253\end{array}$ & LC-MSIMS & $<4$ & $\begin{array}{l}13.6 \\
148\end{array}$ & $<4$ & $<4$ & $\begin{array}{l}31.5 \\
31.0\end{array}$ & $\begin{array}{l}20.0 \\
20.9\end{array}$ & $\begin{array}{l}15.2 \\
12.9\end{array}$ & $\begin{array}{l}14.7 \\
13.3\end{array}$ & $\begin{array}{l}31.5 \\
31.0\end{array}$ & $\begin{array}{l}33.6 \\
35.7\end{array}$ & $\begin{array}{l}15.2 \\
12.9\end{array}$ & $\begin{array}{l}14.7 \\
13.3\end{array}$ & $\begin{array}{c}n / r \\
235.5\end{array}$ & $\begin{array}{c}\mathrm{n} / \mathrm{r} \\
307.0\end{array}$ \\
\hline 253 & LC-MS/MS & n/d & 14.8 & n/d & n/d & 31.0 & 20.9 & 12.9 & 13.3 & 31.0 & 35.1 & 12.9 & 13.3 & & 307.0 \\
\hline & NIST Value & & & & & 1880 & & 1238 & 1238 & 2930 & 33.20 & 12.38 & 12.38 & 238.6 & 334.0 \\
\hline & $U_{9}$ & $\begin{array}{l}0.04 \\
0.06\end{array}$ & $\begin{array}{c}13.30 \\
0.30\end{array}$ & 0.00 & 0.00 & 1.10 & 0.50 & 0.28 & 0.28 & 1.10 & 0.60 & 0.28 & 0.28 & 3.9 & 5.2 \\
\hline
\end{tabular}


Appendix B-2. Raw participant data and NIST results for 3-epi-25(OH)D 3 in SRM 972a L1, SRM 972a L3, and SRM 968d L1

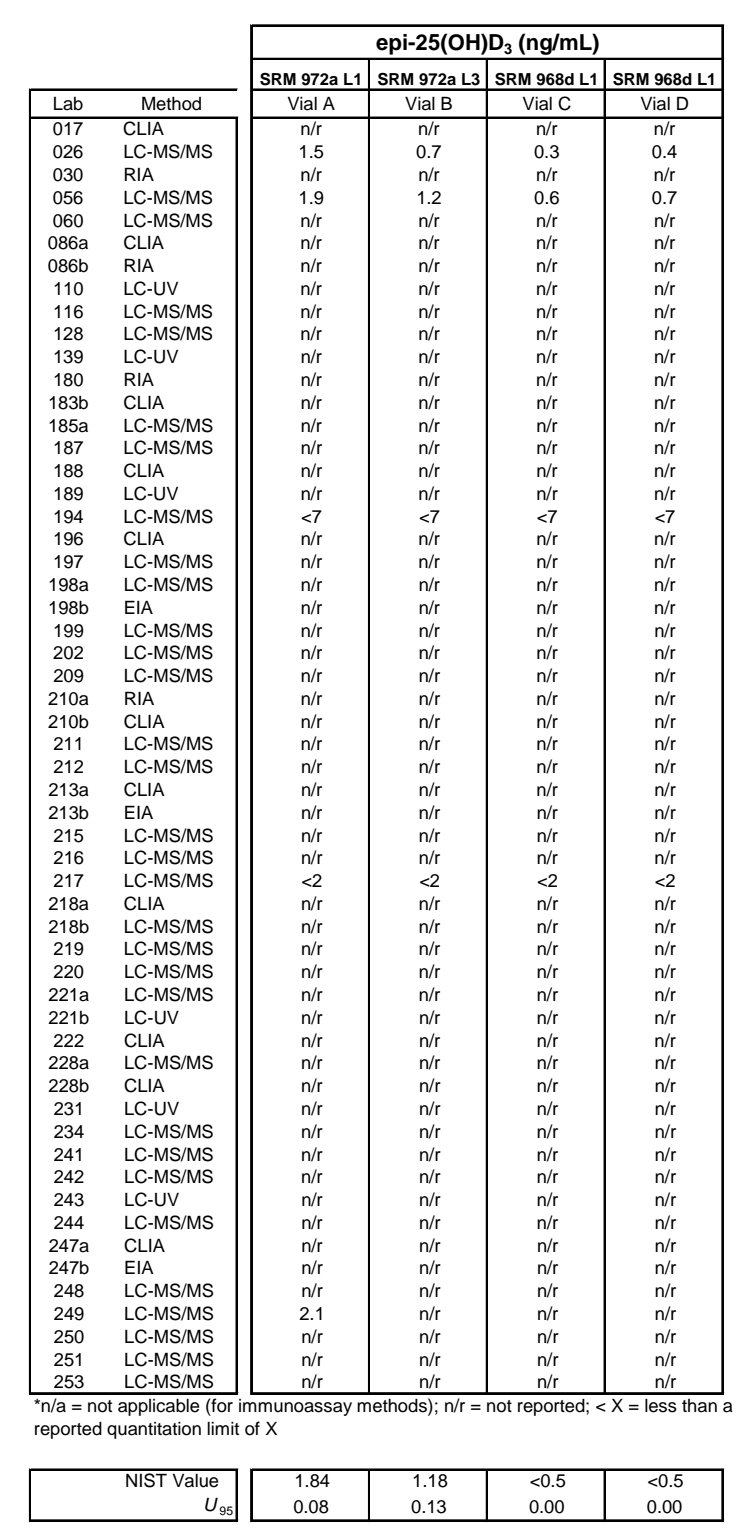

